\title{
Current and future potential of solar and wind energy over Africa using the RegCM4 CORDEX-CORE ensemble
}

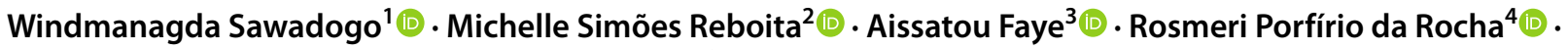

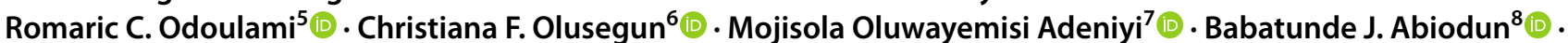 \\ Mouhamadou Bamba Sylla ${ }^{9}$. Ismaila Diallo ${ }^{10}$ (D) Erika Coppola ${ }^{11}$ (D) Filippo Giorgi ${ }^{11}$ (D)
}

Received: 31 December 2019 / Accepted: 11 July 2020 / Published online: 27 July 2020

(c) The Author(s) 2020

\begin{abstract}
Renewable energy is key for the development of African countries, and knowing the best location for the implementation of solar and wind energy projects is important within this context. The purpose of this study is to assess the impact of climate change on solar and wind energy potential over Africa under low end (RCP2.6) and high end (RCP8.5) emission scenarios using a set of new high resolution $(25 \mathrm{~km})$ simulations with the Regional Climate Model version 4 (RegCM4) produced as part of the CORDEX-CORE initiative. The projections focus on two periods: (i) the near future (2021-2040) and ii) the mid-century future (2041-2060). The performance of the RegCM4 ensemble mean (Rmean) in simulating relevant present climate variables (1995-2014) is first evaluated with respect to the ERA5 reanalysis and satellite-based data. The Rmean reproduces reasonably well the observed spatial patterns of solar irradiance, air temperature, total cloud cover, wind speed at $100 \mathrm{~m}$ above the ground level, photovoltaic power potential (PVP), concentrated solar power output (CSPOUT) and wind power density (WPD) over Africa, though some biases are still evident, especially for cloud-related variables. For the future climate, the sign of the changes is consistent in both scenarios but with more intense magnitude in the middle of the century RCP8.5 scenario. Considering the energy variables, the Rmean projects a general decrease in PVP, which is more pronounced in the mid-century future and under RCP8.5 (up to 2\%). Similarly, a general increase in CSPOUT (up to $2 \%$ ) is projected over the continent under both the RCP2.6 and RCP8.5 scenarios. The projection in WPD shows a similar change (predominant increase) in the near and mid-century future slices under both RCPs with a maximum increase of $20 \%$. The present study suggests that the RCP2.6 emission scenario, in general, favours the implementation of renewable energy in Africa compared to the RCP8.5.
\end{abstract}

Keywords Renewable energy $\cdot$ RegCM $\cdot$ Future projections $\cdot$ Africa $\cdot$ CORDEX-CORE

\section{Introduction}

Fossil fuels are currently the main sources of energy supply globally. According to the International Energy Agency (IEA), more than $70 \%$ of the global primary energy demand (IEA 2018) is met by fossil fuels due to their affordability, efficiency, and technological maturity. The combustion of fossil fuels, however, releases greenhouse gases into the atmosphere, such as carbon dioxide $\left(\mathrm{CO}_{2}\right)$, which are the main cause of current global warming. The rapid increase of $\mathrm{CO}_{2}$ emissions from fossil fuel burning has raised a red flag

Windmanagda Sawadogo

sawadogowind@gmail.com

Extended author information available on the last page of the article among policymakers, politicians, and scientists because it has the potential to increase the global average surface temperature of the Earth beyond the danger level (Obama 2017; Matthews et al. 2009; Matthews et Caldeira 2008). Nonetheless, energy is the backbone of socio-economic activities and development of any nation. The access to electricity is, therefore, closely linked to the welfare in human development including productivity, health and safety, gender equality, and education (Alstone et al. 2015).

Access to uninterrupted electricity in most African countries remains a challenge. In fact, there is a thin line of separation between population growth and the high demand for electricity access in Africa. About 630 million people in Africa do not have access to electricity, with a low electrification rate of about 35\% (Bertheau et al. 2017). According 
to the World Bank, about 25 Sub-Saharan African countries are facing an energy crisis evidenced by continuing blackouts (Hancock 2015). Additionally, the average per capita electricity consumption in Sub-Saharan Africa is $488 \mathrm{kWh}$ a year, which is the lowest per capita electricity consumption in the world (Avila and Kammen 2018). The gap between electricity supply and demand is still high over the continent due to poor electricity production from existing electricity generation plants and the lack of modern infrastructures. To meet the electricity demand in a climate-friendly manner, African countries thus need alternative modern energy systems.

Renewable energy is the key to the expansion of a modern energy system especially for developing countries in Africa. Renewable energy is defined as a clean and free energy source naturally replenishable without being exhausted (Owusu and Asumadu-Sarkodie 2016). Among the renewable energy sources currently used for electricity generation, solar and wind energy are the most promising and widely used (IEA 2019). The Levelized Cost of solar and wind energy technologies have dropped substantially during the last decade (Braff et al. 2016) and their costeffectiveness in terms of electricity price is now lower than the use of fossil fuels for electricity generation (Kåberger 2018). Furthermore, solar and wind energy technologies may help least developed countries to increase independent access to electricity for people and run socio-economic activities. However, solar and wind energy mainly depends on solar irradiance and wind speed, which are sensitive to natural variability and changes in the climate system. There is, therefore, a need to investigate how climate change may influence the potential for solar and wind energy over Africa before promoting and investing in such energy systems.

Many studies have assessed the impact of climate change on wind and solar energy around the world. For instance, Carvalho et al. (2017) projected a general decrease in wind energy density in Europe, particularly in Eastern Europe (except the Baltic Sea) and the Mediterranean under both the RCP8.5 and RCP4.5 scenarios. Davy et al. (2018) reported similar results, where they projected a general decrease in wind power density over most of Europe. Conversely, Reboita et al. (2017) found for the end of the century, under the RCP8.5 scenario, an increase in wind intensity and wind power density at $100 \mathrm{~m}$ height over the northern regions of South America, central-east Brazil, and latitudes higher than $50^{\circ} \mathrm{S}$. At the global warming levels of $1.5,2.0,2.5$, and $3.0^{\circ} \mathrm{C}$, wind power density was found to increase over West Africa under the RCP8.5 scenario by Sawadogo et al. (2019a). Similarly, Soares et al. (2019a), using a coupled ocean ( $25 \mathrm{~km}$ resolution)-atmosphere (50 km resolution) regional model, projected an increase in wind energy density in the northern regions of Africa and a decrease in the southern ones. On the other hand, over Southern Africa, Fant et al. (2016) projected small changes in wind speed at $50 \mathrm{~m}$ above the ground level by 2050 .

The impacts of climate change on solar energy are also well-acknowledged in the literature (e.g. Tobin et al. 2018; Wild et al. 2015; Jerez et al. 2015; Burnett et al. 2014; Crook et al. 2011). For instance, a reduction of direct normal irradiation over Africa (up to 10\%) and an increase over Europe (up to 10\%) were projected by Huber et al. (2016). Bazyomo et al. (2016) also projected a general decrease of PV power generation over West African countries, except for Sierra Leone. Using an ensemble of regional climate models (RCMs) from the Coordinated Regional Climate Downscaling Experiment (CORDEX; Giorgi et al. 2009), Sawadogo et al. (2019b) projected a general decrease of photovoltaic power potential (PVP) over West Africa under RCP8.5, with a maximum decrease reaching $3.8 \%$. Likewise, Bichet et al. (2019) projected an average decrease of PVP of about $4 \%$ over most of Africa by the end of the century. At the seasonal scale, most of the Southern African countries are found to possibly experience a decrease in solar irradiance during June-July-August by 2050 (Fant et al. 2016). Additionally, Tang et al. (2019b) projected a significant increase in solar irradiance in December-January-February over Southern Africa under both the RCP4.5 and RCP8.5 scenarios by 2100 and Soares et al. (2019b) found an increase in PV power potential over Southern Africa and a decrease in Eastern Central Africa under the RCP 4.5 and RCP 8.5 scenarios.

Clearly, results are still uncertain and often mixed concerning the future potential of solar and wind energy over Africa under a warming climate, and more data and analyses are needed to provide more robust information toward the development of energy production strategies. To date, most studies employed models with relatively coarse resolution, up to $50 \mathrm{~km}$, or single model and scenario approaches. The CORDEX - Coordinated Output for Regional Evaluations (CORE) initiative was established to provide a homogeneous fine horizontal resolution ensemble of RCM projections over multiple CORDEX domains for application to climate change impact studies (Gutowski et al. 2016). The CORDEX-CORE protocol establishes that a homogeneous set of twenty-first century projections are completed with a set of RCMs over all CORDEX domains at relatively high resolution (25 km grid spacing) driven by multiple GCMs for multiple scenarios. The RegCM4 model (Giorgi et al. 2012) is one of the RCM systems that have actually completed these projections and the resulting dataset is thus an optimal resource to revisit the issue of the effects of climate change on potential energy production. Compared to previous CORDEX experiments over Africa, the CORDEX-CORE ones have higher resolution and consistency across scenarios.

Taking advantage of the availability of this dataset, we here assess its use for the study of current and projected 
PVP, concentrated solar power output (CSPOUT), and wind power density (WPD) over the entire Africa continent. We examine results for two greenhouse gas (GHG) concentration scenarios, the low end RCP2.6 and high end RCP8.5, and for a near term (2021-2040) and mid-century (2041-2060) time slice. Before discussing the future projections, we also present an analysis of present day simulated variables of relevance to wind and solar energy production. In the next section we describe the datasets and metrics used, and then in Sect. 3 we proceed to the discussion of the present day and future projection results.

\section{Models and methods}

\subsection{Model description}

We analyze simulations conducted with the latest version of the Abdus Salam International Centre for Theoretical Physics (ICTP) Regional Climate Model, namely RegCM version 4 (hereafter RegCM4; Giorgi et al. 2012). The RegCM4 simulations for CORDEX-CORE were nested in three CMIP5 (Coupled Model Intercomparison Project-Phase 5) Earth System Models (ESMs): Hadley Center Global Environment Model version 2 (HadGEM2-ES; Collins et al. 2008), Max Planck Institute Earth System Model (MPI-ES-MR; Giorgetta et al. 2013) and Norwegian Earth System Model (NorESM-1 M; Bentsen et al. 2012). These models were chosen as common GCMs to downscale in the first phase of CORDEX-CORE because a preliminary analysis indicated that they perform relatively well over most CORDEX domains and are representative of the climate sensitivity spread in the CMIP5-ESM ensemble (Elguindi et al. 2014).

RegCM4 uses a horizontal grid spacing of $25 \mathrm{~km}$ and 23 sigma-pressure vertical levels over a domain covering the whole African continent and parts of adjacent oceans. The simulations span the period from 1970 to 2100 for two future representative concentration pathways (RCP), i.e., the RCP2.6 (low GHG concentrations) and RCP8.5 (high GHG concentrations) (Moss et al. 2010). Therefore, in total we analyze 6 projections (three driving GCMs, two forcing scenarios), and we focus on the period 1995-2014 as reference present day conditions common to both scenarios, 2021-2040 for near future and 2041-2060 for mid-century conditions. RegCM4 includes a wide choice of physics schemes, and based on a series of preliminary experiments the ones reported in Table 1 were selected.

\subsection{Data}

We use three types of datasets for the model analysis. First, RegCM4 output obtained from the Earth System Grid Federation (ESGF) data node for the following variables: monthly solar irradiance (Rs), surface air temperature (TAS), total cloud cover (clt), and wind speed (wspd) at $100 \mathrm{~m}$ above the ground level (AGL). We then use data from the ERA5 reanalysis product (herein ERA5; Hersbach et al. 2019) for the validation of the model present day period. ERA5 is the fifth-generation reanalysis from the European Centre for Medium-Range Weather Forecasts (ECMWF) with a horizontal grid spacing of $\sim 31 \mathrm{~km}$. It was built from the Era-Interim dataset and provides a high spatial and temporal resolution reference data. Note that, although ERA5 is an advanced dataset with assimilation of observations, improving on several aspects of the previous ERA-Interim product, it is still a model product characterized by some systematic biases (Dullaart et al. 2020; Wang et al. 2019; Tall et al. 2019). From ERA5 we use monthly TAS, clt, and wind speed at $100 \mathrm{~m}$ for the reference period 1995-2014.

Finally, the Satellite Application Facility on Climate Monitoring (CM-SAF) second edition of the Surface Solar Radiation Data Set-Heliosat Edition 2 (SARAH-2; Pfeifroth et al. 2018) is used for further model evaluation. SARAH-2 is a product derived from satellite observations on the visible channels of the MVIRI and the SEVIRI instruments onboard the geostationary Meteosat satellites. Satellite based observations are characterized by lower uncertainties than the reanalysis dataset due to higher accuracy (Boilley et Wald 2015) and they are widely used to evaluate the solar irradiance simulated by climate models (Tang et al. 2019b; Sawadogo et al. 2019b; Bichet et al. 2019). From the CM-SAF platform, we retrieved monthly Rs for the period 1995-2014.

Table 1 Parameterizations used in the RegCM4 simulations for the CORDEX-CORE Africa domain

\begin{tabular}{lll}
\hline Parameterization & Schemes used & References \\
\hline Boundary layer processes & Holtslag & (Holtslag et al. 1990; Holtslag and \\
Boville 1993) \\
Interaction surface-atmosphere & Community land model version 4.5 (CLM4.5) & (Oleson et al. 2008) \\
Turbulent fluxes over sea & Zeng scheme & (Zeng et al. 1998) \\
Cumulus convection & Tiedtke over the land and Kain-Fritsch over the sea & (Tiedtke 1989; Kain-Fritsch 1990) \\
Radiation scheme & NCAR community climate model 3 & (Kiehl et al. 1996) \\
Large scale precipitation & Subgrid explicit moisture scheme (SUBEX) & (Pal et al. 2000) \\
\hline
\end{tabular}


Note that the Rs from SARAH-2 dataset is derived from a cloud index (from satellite observation), water vapour, surface albedo, aerosols and ozone (from climatology data) through a radiative transfer model. For simplicity in this study ERA5 and SARAH-2 dataset are referred to as observations, but it should be acknowledged that these are ultimately model products possibly characterized by systematic biases.

\subsection{Methodology}

\subsubsection{Solar energy}

2.3.1.1 Concentrated solar power Concentrated solar power (CSP) systems use direct irradiance (Rd) through a combination of mirrors or lenses to produce energy in the form of electricity and heat. We estimate the CSP using the approach proposed by Crook et al. (2011), which requires the thermal efficiency of CSP $\left(\eta_{\mathrm{CSP}}\right)$ and Rd. Since Rd is not available from the model, we derive it from an empirical relationship between the fractional cloud cover (fclt) and the clear sky irradiance at the surface (Rsc) as (Edwards and SLingo 1996):

$\mathrm{Rd}=0.75 \times \operatorname{Rsc} \times(1-\mathrm{fclt})$

where the factor 0.75 represents the effect of sunlight scattering by air molecules and aerosols.

Also, Rsc is not available from the model output, and therefore we use a method defined by Deardorff (1978) to link the fractional cloud cover (fclt), solar irradiance (Rs) and Rsc as follows:

fclt $=1-$ Rs $/$ Rsc

which, by substitution in Eq. (1) leads to

$\mathrm{Rd}=0.75 \mathrm{Rs}$

The $\eta_{\mathrm{CSP}}$ can then be computed as:

$\eta_{\mathrm{CSP}}=k_{0}-k_{1} \frac{\left(T_{\mathrm{i}}-\mathrm{TAS}\right)}{\mathrm{Rd}}$

where $k_{0}=0.762 \mathrm{Wm}^{-2}{ }^{\circ} \mathrm{C}^{-1}$ and $k_{1}=0.2125 \mathrm{Wm}^{-2}{ }^{\circ} \mathrm{C}^{-1}$ are the collector specific coefficients, and $T_{\mathrm{i}}=115^{\circ} \mathrm{C}$ is the temperature of the fluid. The coefficients have been tested for an Industrial Solar Technology parabolic trough collector at Sandia National Laboratories and used by Crook et al. (2011) and Wild et al. (2017). TAS is the ambient air temperature, taken from the model.

Finally, CSP is given by:

$\mathrm{CSPOUT}=\eta_{\mathrm{CSP}} \cdot \mathrm{Rd}$
2.3.1.2 Photovoltaic power potential The photovoltaic power potential (PVP) can be estimated using the power rating or the energy rating method. The power rating method uses the integration of instantaneous photovoltaic power generation over time, while the energy rating method estimates the photovoltaic potential by multiplying the total solar irradiance during a specific period of time by a performance ratio (Dubey et al. 2013). Similarly, to previous studies (Jerez et al. 2015; Sawadogo et al. 2019b; Bichet et al. 2019), here we use the energy rating method, and in particular we quantify the PVP following Mavromatakis et al. (2010):

$\operatorname{PVP}(t)=P_{\mathrm{r}}(t) \cdot \frac{R_{\mathrm{S}}(t)}{R_{\mathrm{STC}}}$

where $R_{S T C}$ is the solar irradiance at Standard Test Conditions (STC), which is equal to $1000 \mathrm{~W} / \mathrm{m}^{2} . P_{r}(t)$ is referred to as the performance ratio, which accounts for changes in the efficiency of the photovoltaic cells due to changes in temperature (Jerez et al. 2015) and is computed as:

$P_{\mathrm{r}}(t)=1+\gamma \cdot\left[T_{\text {cell }}-T_{\mathrm{STC}}\right]$

where $T_{\mathrm{STC}}$ is the ambient air temperature at STC and is equal to $25^{\circ} \mathrm{C}$. The constant $\gamma$ depends on the type of solar cell, and we use in this study a monocrystalline silicon solar cell (the most used in Africa) for which $\gamma$ takes the value of $-0.005{ }^{\circ} \mathrm{C}^{-1}$ (Jerez et al. 2015). $T_{\text {cell }}\left({ }^{\circ} \mathrm{C}\right)$ is the solar cell temperature, which depends on solar irradiance, air temperature, wind speed and relative humidity (TamizhMani et al. 2003). Recent studies have shown that the contribution of wind speed and relative humidity to changes in PVP is negligible in Africa (Sawadogo et al. 2019b; Bichet et al. 2019). Therefore, $T_{\text {cell }}$ is expressed as a function of solar irradiance (Rs) and air temperature (TAS) as:

$T_{\text {cell }}=c_{1}+c_{2} \cdot \mathrm{TAS}+c_{3} \cdot R s$

The coefficients $c_{1}=3.75{ }^{\circ} \mathrm{C}, \quad c_{2}=1.14$, and $c_{3}=0.0175{ }^{\circ} \mathrm{C} \mathrm{m}^{2} \mathrm{~W}^{-1}$ for a monocrystalline silicon cell were taken from Lasiner and Ang (Lasnier and Ang 1990) and used in (Crook et al. 2011).

\subsubsection{Wind power density (WPD)}

The wind power density (WPD) is an indicator of the potential of wind energy generation in a location. Here $\mathrm{WPD}\left(\mathrm{W} / \mathrm{m}^{2}\right)$ is expressed as:

$\mathrm{WPD}=1 / 2 \rho V^{3}$ 
Fig. 1 RegCM4 topography (m) of the CORDEX-Africa domain. The boxes indicate the different sub-regions used in this study for more specific analysis: West Africa (WAF), North Africa (NAF), Central Africa (CAF), East Africa (EAF), and Southern Africa (SAF)

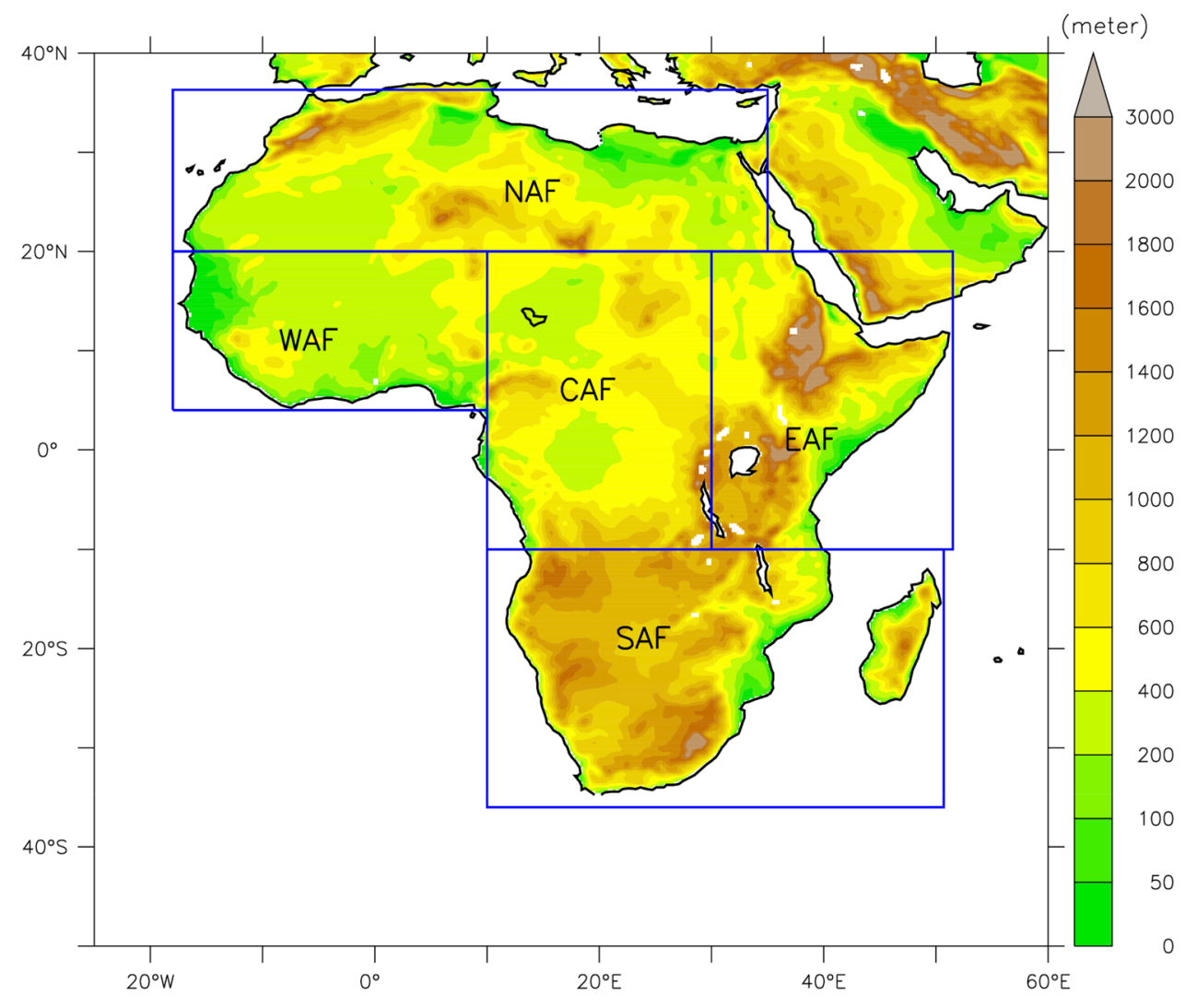

where $\rho$ is air density $\left(\mathrm{kg} / \mathrm{m}^{3}\right)$ and $V$ is wind speed $(\mathrm{m} / \mathrm{s})$ at the desired height. Since $\rho$ is a function of elevation $(Z)$, we estimate it following Custódio (2009):

$\rho \cong \frac{353.4\left(1-\frac{Z}{45271}\right)^{5.2624}}{273.15+T}$

where $\mathrm{Z}$ is the elevation (in meter) and $\mathrm{T}$ is the air temperature at $100 \mathrm{~m}$. The parameter $\mathrm{T}$ is calculated by considering a dry adiabatic lapse rate of about $1{ }^{\circ} \mathrm{C}$ per $100 \mathrm{~m}$ (Wallace and Hobbs 2006). The same method was used by Reboita et al. (2017) to estimate $\rho$ in the calculation of WPD over Southern America.

To compute WPD, most studies extrapolate the surface wind speed (generally at $10 \mathrm{~m}$ ) to the desired height with different approaches due to the unavailability of the wind speed at a general elevation $Z$. These approaches have been reported to underestimate the wind speed in stable conditions and overestimate it in unstable conditions (Gualtieri and Secci 2012). Here, we use the wind speed at $100 \mathrm{~m}$ above ground level (AGL), which is a standard output of RegCM4. This wind speed is computed using a linear interpolation between adjacent model sigma levels of the zonal and meridional wind components.

\subsubsection{Analyses}

Our analysis consists of two phases. First, we evaluate the capability of the RegCM4 driven by the three ESMs (HadGEM2-ES, MPI-ES-MR, and NorESM-1 M) and its ensemble mean (hereafter referred as Rmean) in reproducing present day (1995-2014) variables related to renewable energy potential (PVP, CSPOUT, and WPD) along with some key atmospheric variables (Rs, clt, TAS, and wspd). We stress that since there is no assimilation of observations, this validation exercise is carried out only in a statistical sense, and not for individual events or years.

We then analyse changes with respect to the reference period 1995-2014 in these energy-related variables for the two scenarios, RCP2.6 and RCP8.5, and two time slices near-term (2021-2040) and mid-century (2041-2060). Both for the climate and energy variables the analysis is based on monthly values, the annual means are calculated as averages of these monthly values, and the ensemble average is computed by averaging over all ensemble members. We define the projected changes as the difference between the future and reference periods expressed either as absolute values (for TAS) or as percentage of reference values (all other variables). Furthermore, we assess the robustness of 

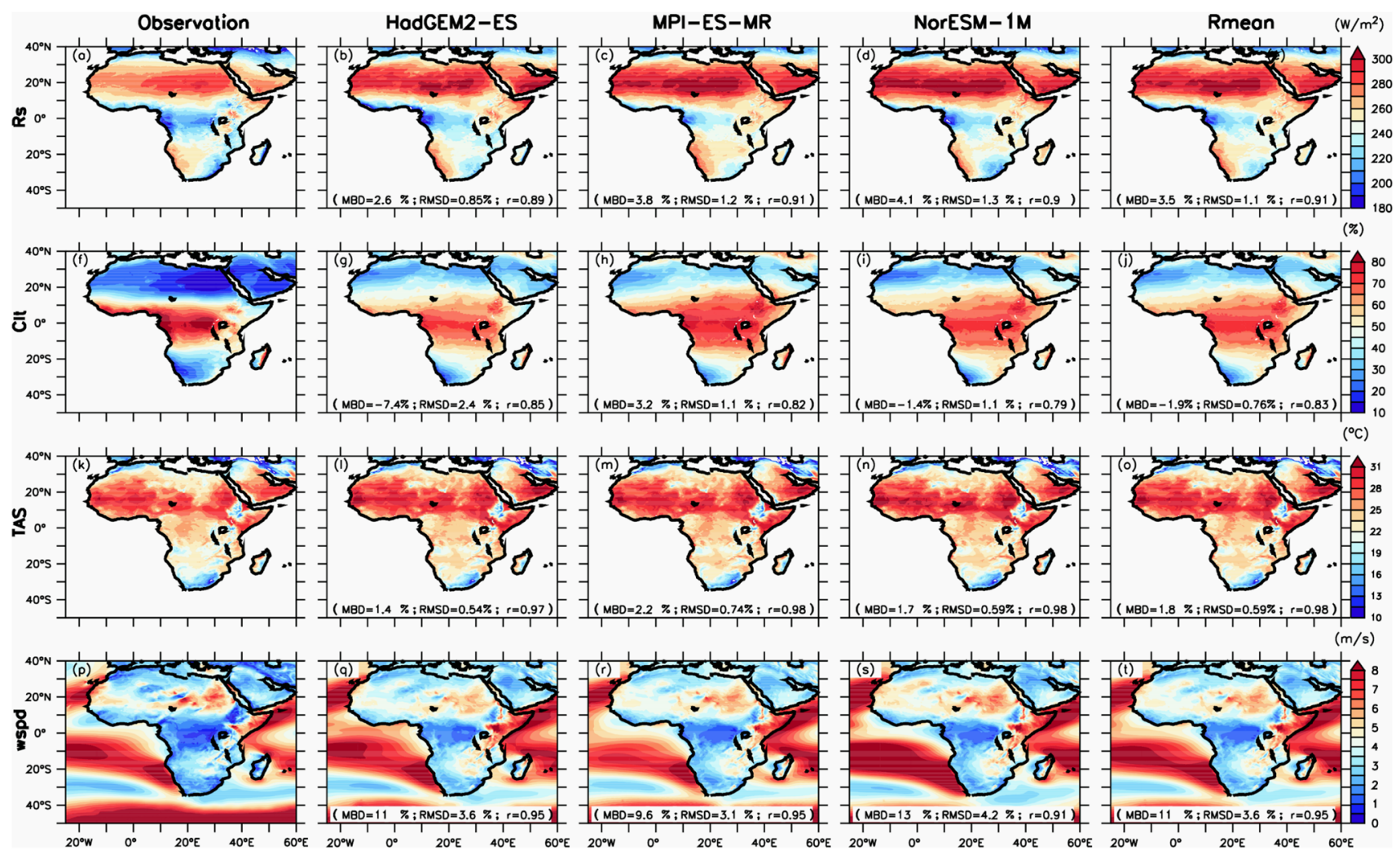

Fig. 2 Annual mean of solar irradiance (Rs), total cloud cover (clt), air temperature (TAS), and wind speed (wspd) at $100 \mathrm{~m}$ AGL in the present climate (1995-2014) of the RegCM4 driven by three ESMs (HadGEM2-ES, MPI-ES-MR, and NorESM-1 M) and its ensemble mean (Rmean). The MBD, RSMD, and $r$ indicate, respectively, the spatial mean bias, root-mean-square deviation and spatial pattern correlation between observations and simulations over the whole of Africa
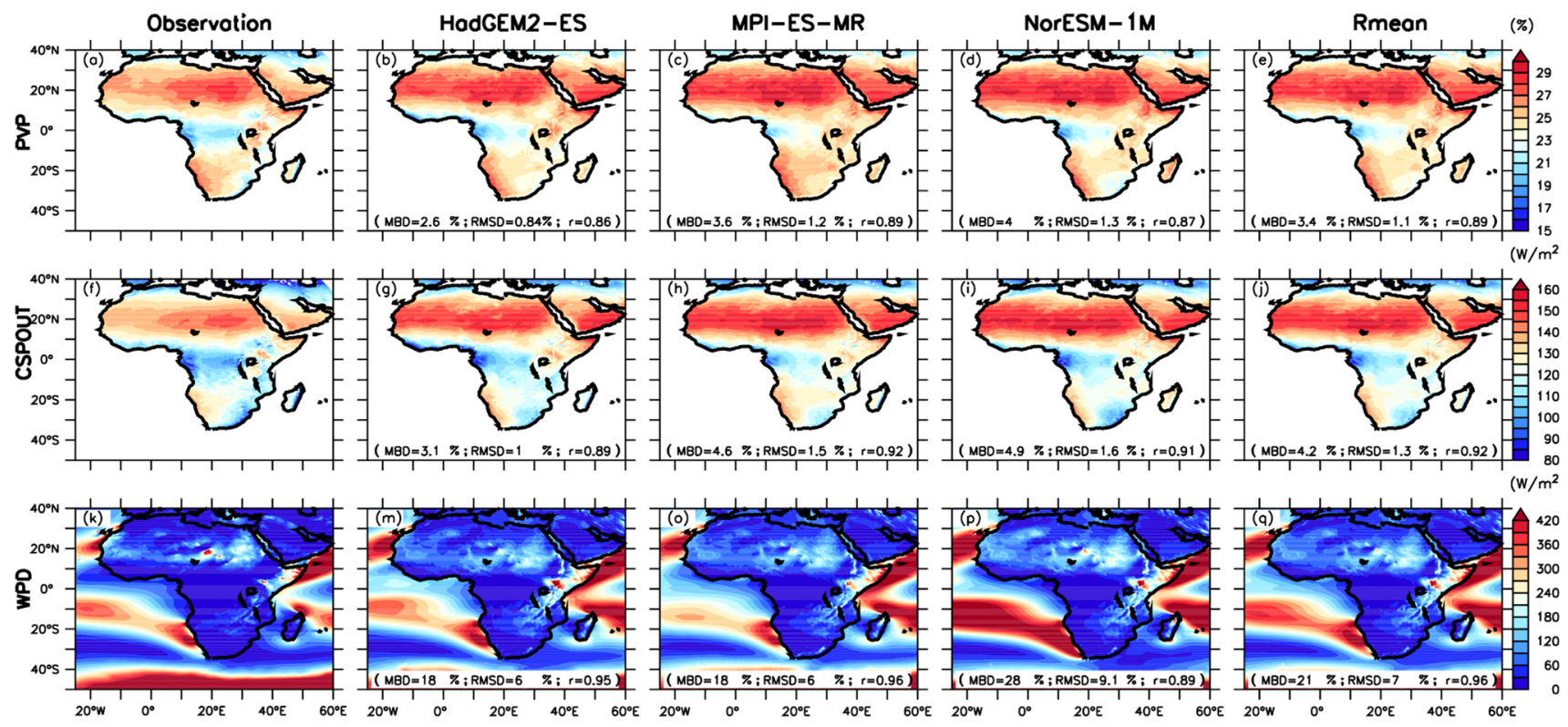

Fig. 3 Annual mean of PV power potential (PVP), concentrated solar power out (CSPOUT), and wind power density (WPD) at $100 \mathrm{~m}$ above the ground level in the present climate (1995-2014) of the RegCM4 driven by three GCMs (HadGEM2-ES, MPI-ES-MR, and
NorESM-1 M) and its ensemble mean (Rmean). The MBD, RSMD, and $\mathrm{r}$ indicate the spatial mean bias, root-mean-square deviation, and spatial pattern correlation between observations and simulations 
Fig. 4 Boxplot of the spread of the three individual RegCM4 simulations and the mean value of observation (dot) over the sub-domains in a PVP, $\mathbf{b}$ CSPOUT, and $\mathbf{c}$ WPD. Each boxplot indicates the minimum, first quartile, median, third quartile and maximum of RegCM4 spread
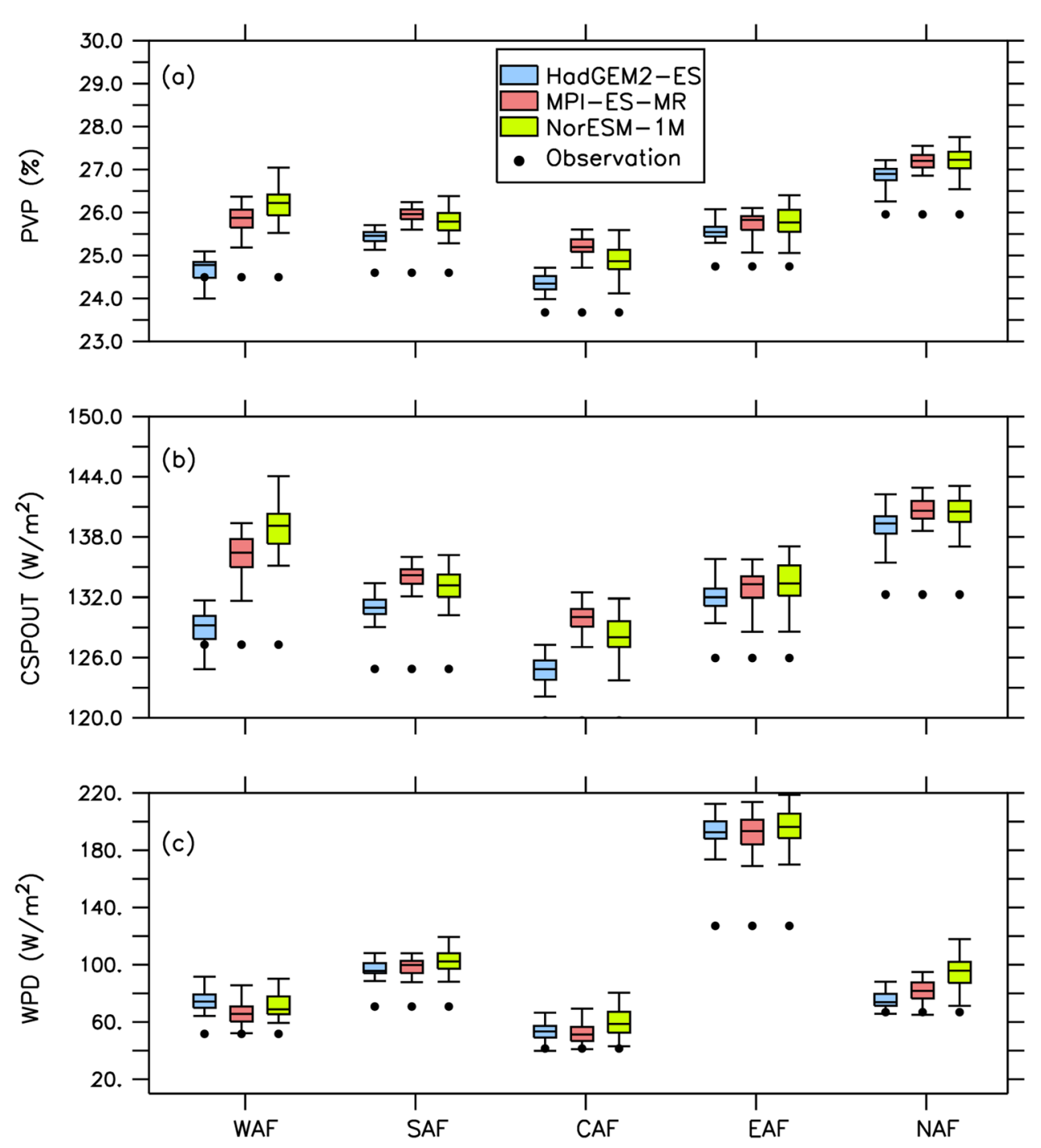

the simulated changes by (1) the level of agreement across simulations, e.g. when all the individual ensemble members agree on the sign of the change; and (2) when at least one of the individual members indicate that the projected change is statistically significant at the $90 \%$ confidence level based on a student t-test. The results are presented for the whole Africa domain and/or for values averaged over the specific sub-regions shown in Fig. 1: West Africa (WAF), North Africa (NAF), Central Africa (CAF), East Africa (EAF), and Southern Africa (SAF).

\section{Results and discussions}

\subsection{Model evaluation}

Figure 2 presents the annual mean for the reference period (1995-2014) of solar irradiance (Rs), total cloud cover (clt), air temperature (TAS), and wind speed (wspd) at $100 \mathrm{~m}$
AGL from observations (see Sect. 2), each RegCM4 simulation and Rmean. All the three simulations along with their Rmean reproduce well the observed spatial distribution of Rs, clt, TAS, and wspd at $100 \mathrm{~m}$ AGL across the continent (Fig. 2), with a spatial correlation in the range of 0.83-0.98. For example, in agreement with observations, Rs maximum values are located over the northern Sahel, the eastern Sahara Desert, the Horn of Africa and SouthWestern Africa, while the lowest values occur along the Guinea Coast, over Central Africa, and the Eastern coast of Southern Africa (Fig. 2a-e).

The simulated and observed Rs spatial distributions across the continent show a link with the cloud cover, as lower (higher) Rs values are associated with higher (lower) clt values (see Fig. 2a-e and $\mathrm{f}-\mathrm{j}$ ). In general, high cloud cover is located between $18^{\circ} \mathrm{S}$ and $8^{\circ} \mathrm{N}$, especially along the coast of West Africa and Central Africa (Fig. 2f-j), because of the presence of the Intertropical Convergence Zone and feedbacks with the underlying forest cover. The 

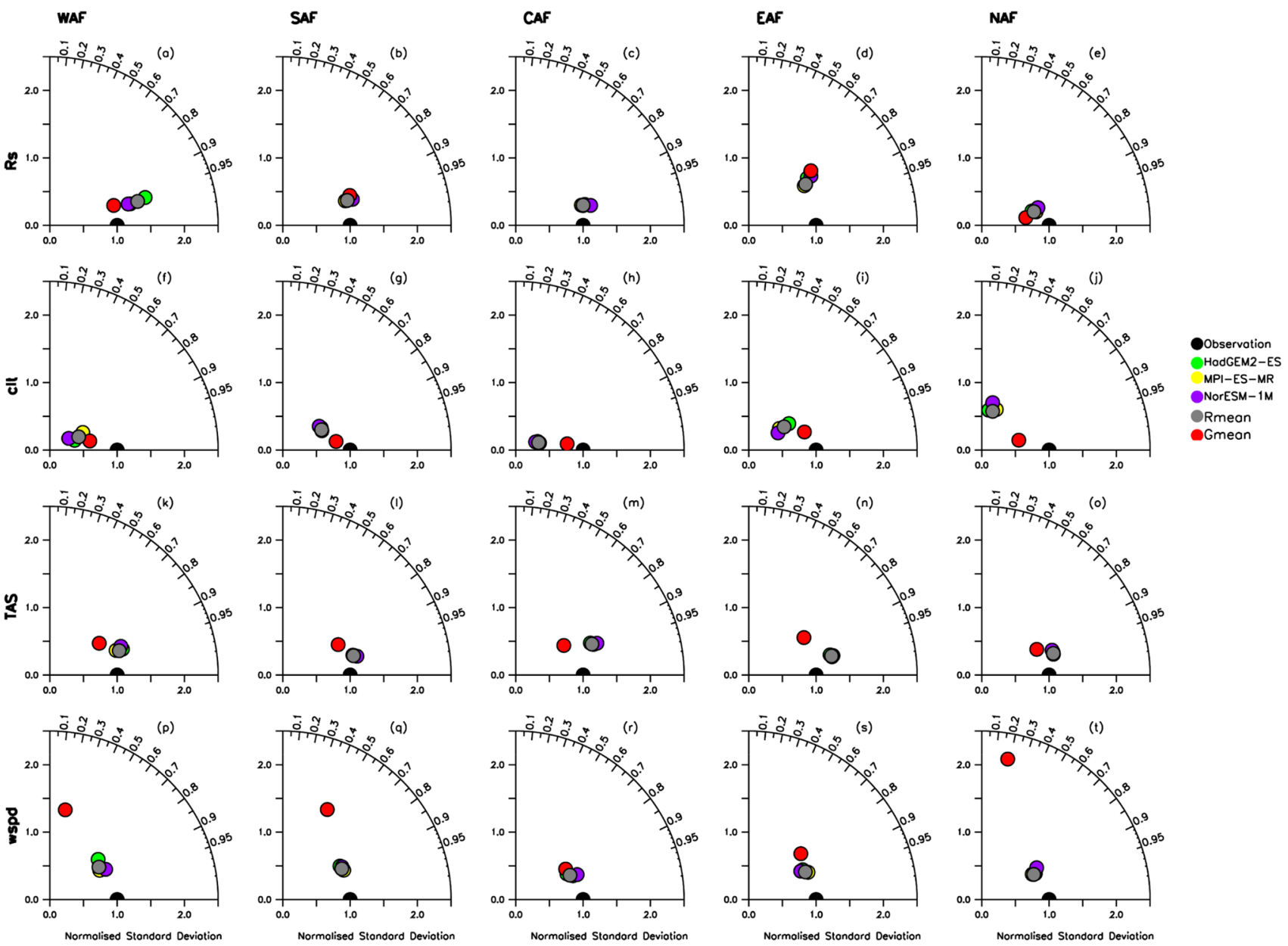

Fig. 5 Taylor diagrams comparing the statistics (spatial correlation and normalised standard deviation) of Rs, TAS, clt, and wspd as simulated by RegCM4 nested in different GCMs (HadGEM2-ES, MPIES-LR, and NorESM-1 M) over the African sub-domains in Fig. 1.

high temperatures along the northern Sahelian band and Sahara are due to desert conditions and/or to less vegetation over this region. Additionally, all datasets exhibit low wind speed (Fig. $2 \mathrm{p}-\mathrm{t}$ ) over the areas with more dense vegetation (mainly between $20^{\circ} \mathrm{S}$ and $0^{\circ}$ ) because the higher aerodynamic roughness reduces the surface wind speed. In agreement with observations, the Rmean locates the highest values of wind speed in the fringe of Northern, Southern, and Eastern Africa.

Despite the capability of the simulations to reproduce the observed spatial distributions, there are still some noticeable biases over the continent (See Appendix; Fig. 11). For instance, all the simulations overestimate Rs along the Sahelian band (up to $20 \mathrm{~W} \mathrm{~m}^{-2}$ ) and underestimate it over most parts of Southern Africa (up to $-6 \mathrm{~W} \mathrm{~m}^{-2}$ ). These biases may be linked to cloud back-scattering or albedo and cloud absorption, but also to the representation of aerosols in climate models and the SARAH-2 datasets (Wilcox et al.
Both spatial correlation and normalised standard deviation are calculated for each simulation and for the ensemble mean of RegCM4 (Rmean) and the GCMs (Gmean)

2013; Wu and Fu 2011). Furthermore, the model simulates less cloud cover than observed over West Africa and overestimates it over most parts of Southern and Central Africa (Fig. 2f-j). The positive bias in cloud cover exceeds $20 \%$, while the negative bias is in the range of 6-8\%, indicating still the presence of shortcomings in the representation of cloud processes in climate models (De Souza et al. 1997; Solomon et al. 2009). The simulated TAS shows a prevailing warm bias across the continent in the range of $0.4-1{ }^{\circ} \mathrm{C}$. Also, the simulated wind speed exhibits a positive bias $\left(1 \mathrm{~m} \mathrm{~s}^{-1}\right)$ over several parts of the continent and negative ones over centralwestern Africa (Fig. 2p-t). Despite these biases we assess that our simulation ensemble has a performance certainly in line with, if not better than, previous applications of the RegCM4 model (e.g. Sylla et al. 2010; Mariotti et al. 2014).

The spatial distribution of the simulated PVP, CSPOUT, and WPD over Africa are similar to the observed, as shown by the high spatial correlation, low root-mean-square 

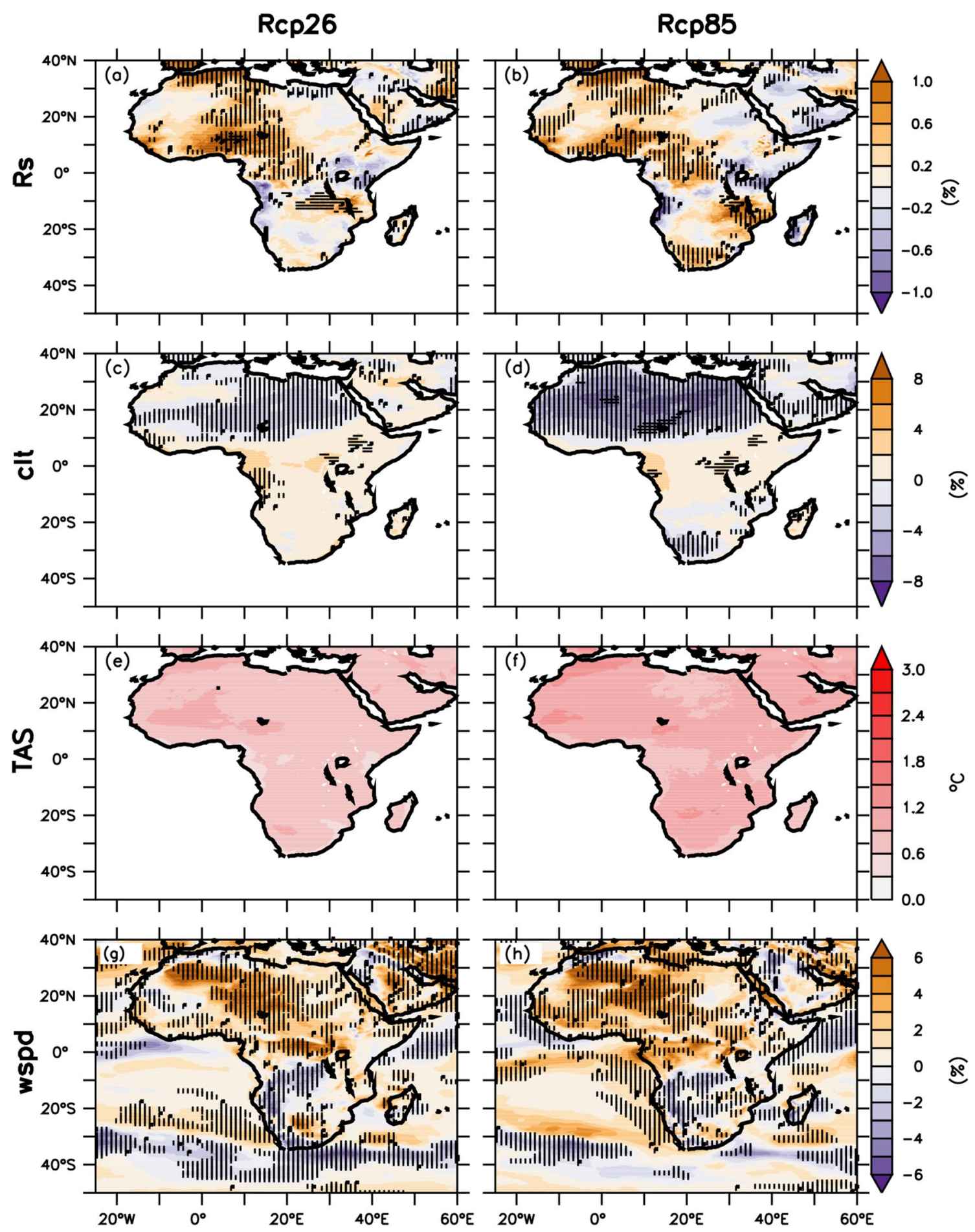

Fig. 6 Rmean projected changes in the annual mean of solar irradiance (Rs), air temperature (TAS), total cloud cover (clt), and wind speed at $100 \mathrm{~m}$ AGL in the near future (2021-2040) under RCP2.6 and RCP8.5 scenarios. The vertical lines indicate the agreement

deviation, and low biases over the continent (Fig. 3). The observed potential for solar energy is characterized by high values of CSPOUT (up to $150 \mathrm{~W} \mathrm{~m}^{-2}$ ) and PVP (about 28\%) between the RegCM4 members while the horizontal lines show the statistically significant change (at 90\% confidence level). All the models agree on the signal and statistical significance of TAS changes over Africa

in the latitudinal band extending from $15^{\circ} \mathrm{N}$ to $30^{\circ} \mathrm{N}$, delineating the northern Sahel and Sahara Desert. This is consistent with the observed Rs over that region and supports 

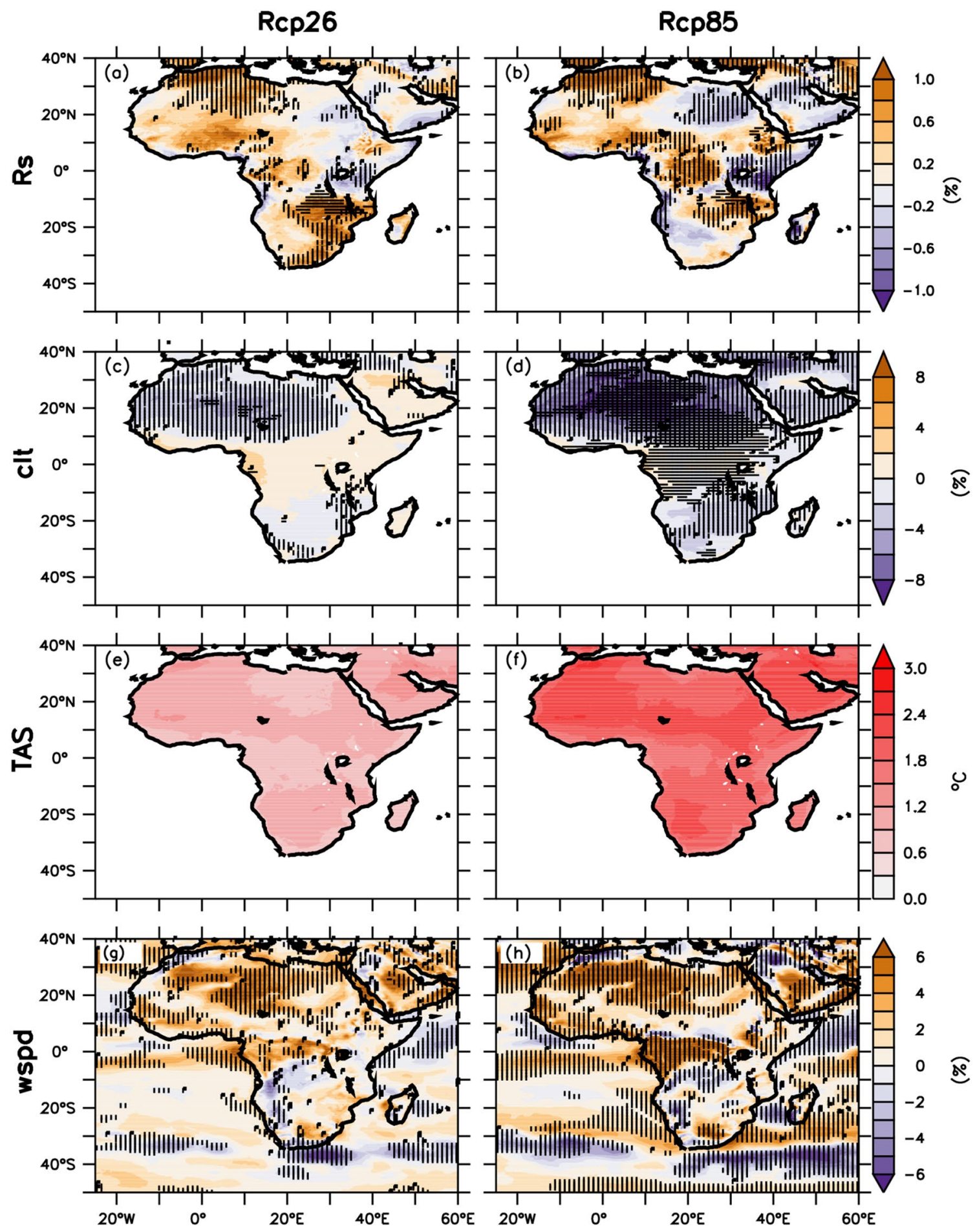

Fig. 7 Similar to Fig. 6, but for the middle future (2041-2060)

the association between Rs and PVP previously reported by Nasrin et al. (2018). The simulations with their Rmean and the observational datasets also agree on the high WPD in the same latitudinal band (like PVP and CSPOUT). Over the ocean, the western coast of Southern Africa and West
Africa along with the coast of East Africa show higher WPD $\left(\sim 400 \mathrm{~W} \mathrm{~m}^{-2}\right)$. Additionally, the eastern regions of the continent present the highest WPD (Fig. 3g, h), with the Rmean showing a negative bias of about $6 \mathrm{~W} \mathrm{~m}^{-2}$ (see Appendix; 


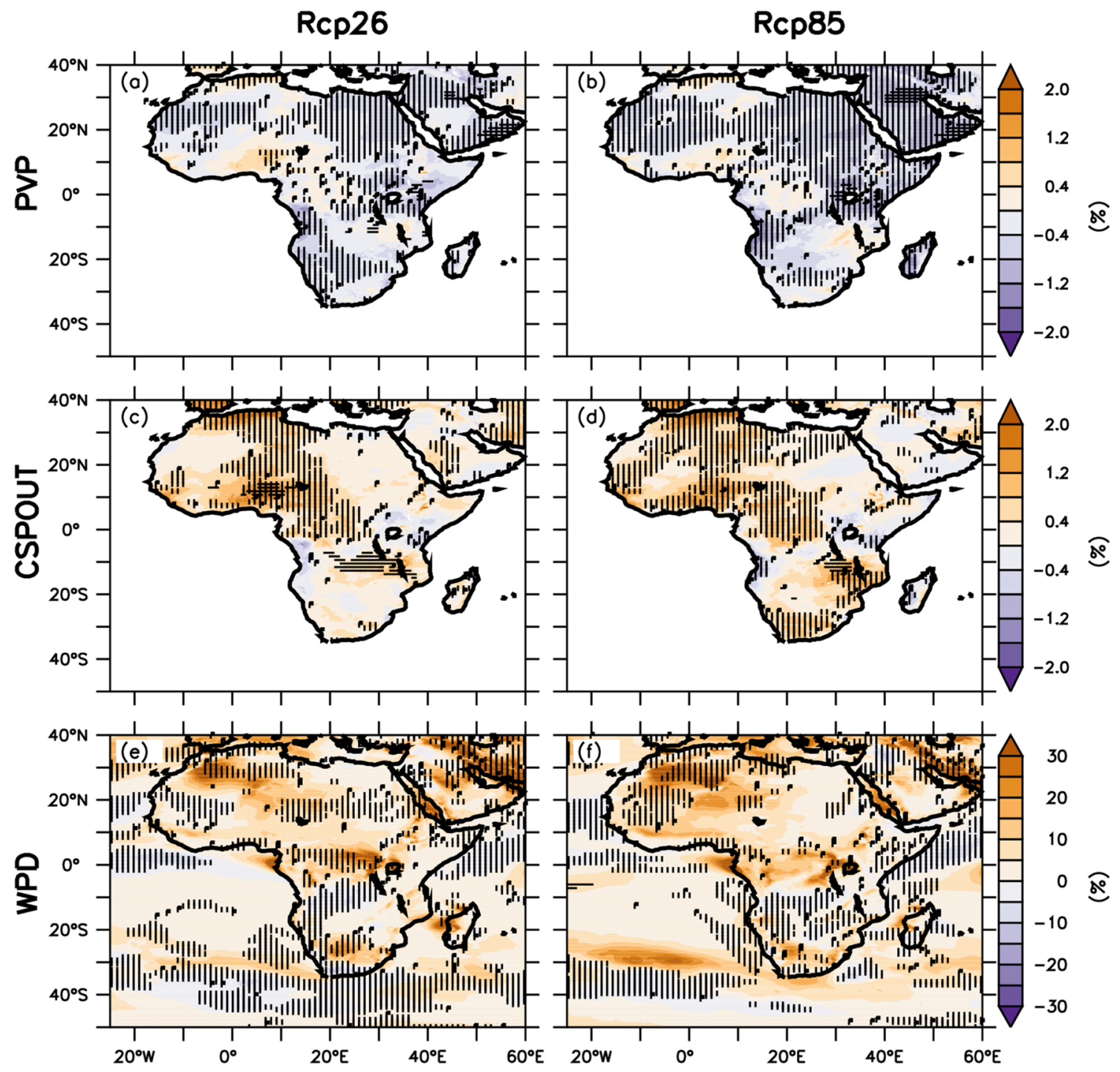

Fig. 8 Rmean projected changes in the annual mean of PV power potential (PVP), concentrated solar power out (CSPOUT), and wind power density (WPD) at $100 \mathrm{~m}$ above the ground level in the near future (2021-2040) under RCP2.6 and RCP8.5 scenarios. The verti-

Fig. 12). For PVP and CSPOUT the simulated biases are consistent with those for Rs.

The performance of the three different simulations visà-vis the observations varies depending on the variables considered. For example, for Rs the RegCM4 nested in HadGEM2-ES exhibits a low MBD (2.6\%) and RMSD $(0.85 \%)$, while RegCM4 nested in the MPI reproduces well the observed spatial pattern (correlation of 0.91) (Fig. 2b). Conversely, for the clt variable, the RegCM4 nested in NorESM-1 M shows better agreement with observations than that forced by HadGEM2-ES and MPI-ES-MR. Similar remarks are valid for TAS and wspd, where the three simulations perform differently. RegCM4 nested in HadGEM2ES performs better in simulating the PVP (Fig. 3b) and the cal lines indicate when all RegCM4 members agree with the sign of the projected changes while the horizontal lines show the statistically significant change (at $90 \%$ confidence level)

CSPOUT (Fig. 3g) while the model performs better for WPD when driven by MPI (Fig. 3o).

Figure 4 presents the mean regional spread of the simulated and observed annual values of PVP, CSPOUT, and WPD over the African sub-regions highlighted in Fig. 1 for each simulation. The spread is measured by the interquartile range of annual values, where we first average each year of the 1995-2014 period across the given region, resulting in 20 mean annual values, from which we then calculate the interquartile range and full spread across years. Overall, most simulations overestimate the mean value of observed PVP and CSPOUT in most subdomains, which may be the result of higher than observed Rs, clt, and TAS. The model performance is better for WPD, with the model 

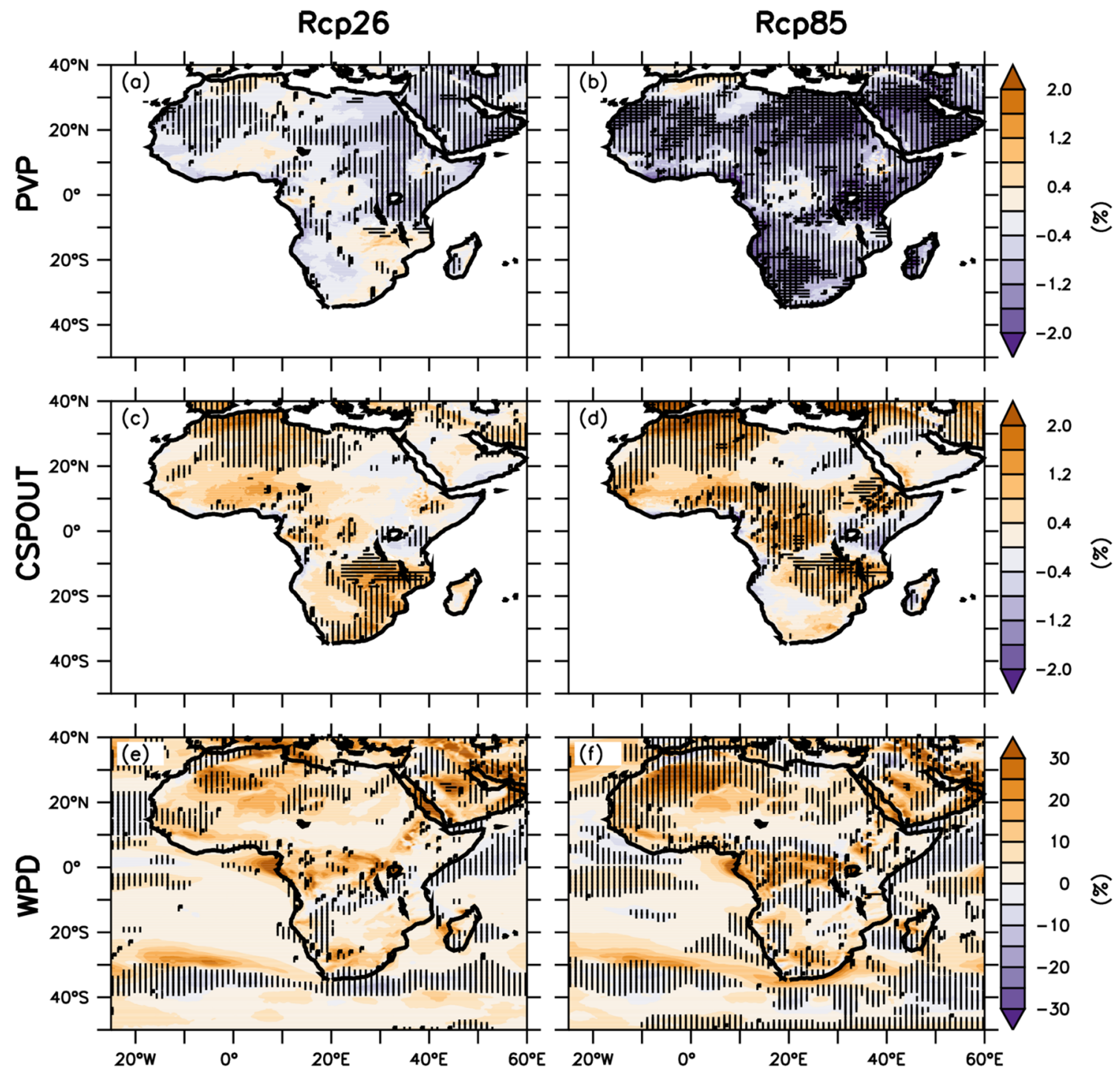

Fig. 9 Similar to Fig. 7, but for the middle future (2041-2060)

being close to observations in all sub-domains except EAF. Despite these systematic biases, which may also be due to uncertainties in the observed estimates, the models reproduce the inter-regional distribution of the variables and the RegCM4 driven by NorESM-1 M shows the highest values. For instance, in agreement with observations, the simulated spread indicates the highest value of PVP over NAF (27.21\%) followed by WAF (27.04\%), while the CSPOUT shows the highest value over WAF $\left(144.05 \mathrm{~W} \mathrm{~m}^{-2}\right)$ followed by NAF (143.05 $\left.\mathrm{W} \mathrm{m}^{-2}\right)$. Finally, the model reproduces the maximum of WPD over EAF. In fact, the East African stands out as the most viable region for the implementation of wind energy technology with the highest WPD median.

We also carried out a comparison of the RegCM4 and driving GCM fields to identify whether any added value is obtained by the regional model nesting. For this purpose, we utilized as a metric the Taylor diagram, which has been highlighted as an optimal measure of added value (e.g. Torma et al. 2015). In fact, the Taylor diagram encompasses three metrics of comparison between simulated and observed spatial distribution of a variable, the correlation, the spatial standard deviation normalized by the observed value, and the centered root-mean-square difference (distance from the observed reference value in the diagram). Figure 5 shows the Taylor diagrams for Rs, clt, TAS and wspd calculated over the 5 sub-regions of Fig. 1. Results are shown for the regional and global model ensemble means, Rmean and Gmean, respectively, and for each RegCM4 simulation.

For Rs, the regional and global model results are quite similar, with a slight advantage for the RegCM4. Both ensembles show high correlations and close to observed spatial standard deviations. Cloudiness is the variable for 

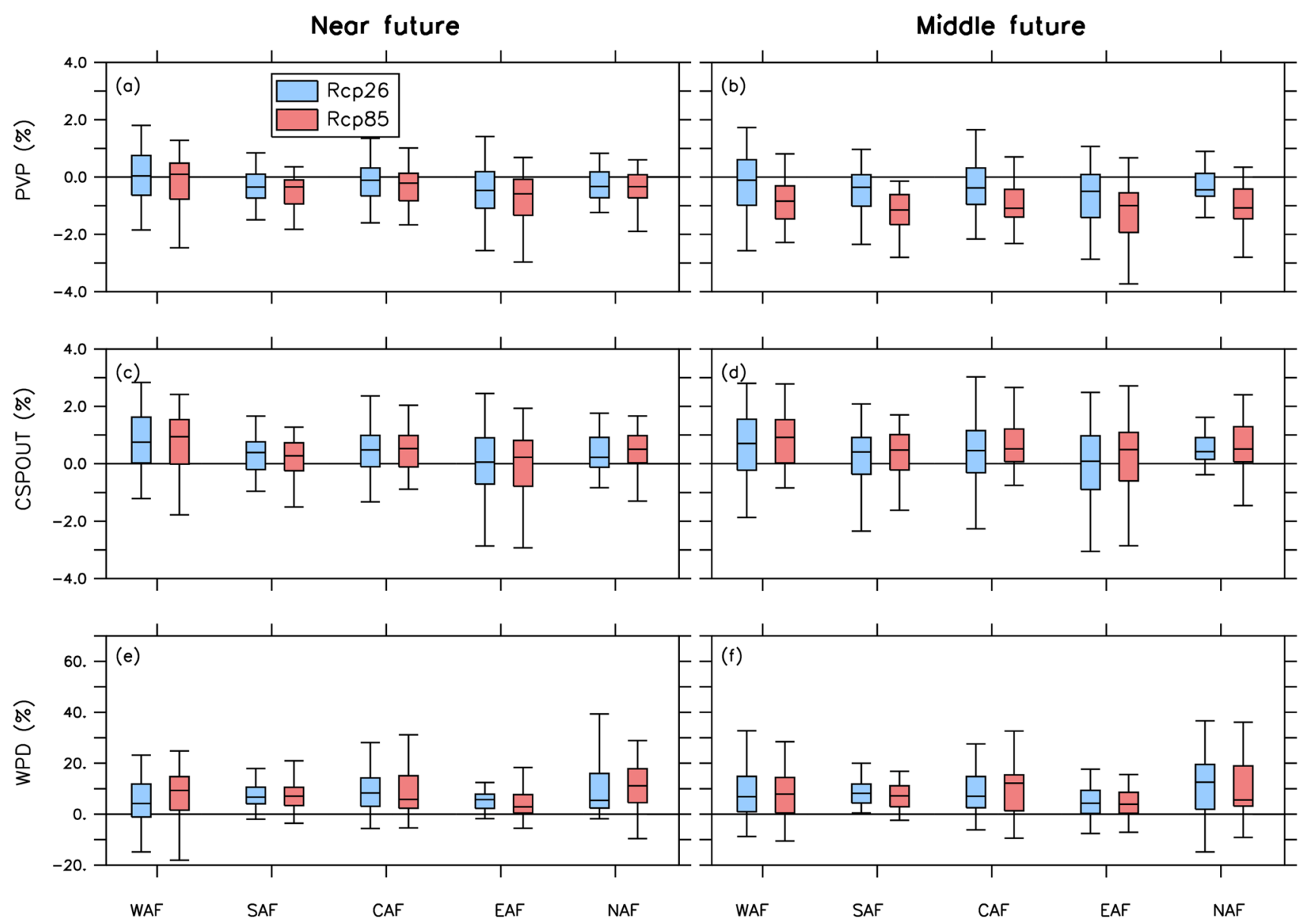

Fig. 10 Projected changes in the annual average of PV power potential (PVP), concentrated solar power out (CSPOUT), and wind power density (WPD) at $100 \mathrm{~m}$ above the ground level of the mean of the 3 individual simulations over African sub-domains in Fig. 1 in the

which the regional model performs most poorly, and is outperformed by the global models. This is due to the persistence in the model of thin high clouds, a feature noted also in previous applications. These clouds do not contribute much to the surface solar radiation, as shown by the Rs field, but strongly affect the calculated total cloud cover, also because in the calculation of clt the model assumes random overlap across the different model levels, which tends to maximize the value of total cover.

The added value of the RegCM4 simulations is already much clearer in the TAS field, again with high correlations and good standard deviations in all regions, but the variable for which this is most clear is the wind speed, since the RegCM4 performs quite well in all regions while the GCMs perform poorly except for CAF and EAF. This better performance in the simulation of wind speed is most likely attributable to the higher resolution of the RegCM4. Finally, we see how the results for the different ensemble members are similar to each other, near future (2021-2040) and middle future (2041-2060) and under RCP2.6 and RCP8.5 scenarios. Each boxplot indicates the minimum, first quartile, median, third quartile and maximum of the 3 simulation means

i.e. the performance of the model for these variables does not depend strongly on the driving GCM boundary conditions.

In summary, this section shows that, despite the presence of systematic biases mostly related to the total cloud cover field (for the reasons highlighted above), the regional model ensemble performs reasonably well in the simulation of solar and wind energy related variables, showing in several instances significant added value compared to the driving GCMs. We turn therefore our attention to the future climate projections.

\subsection{Climate projections}

\subsubsection{Projected changes in climate variables}

Figure 6 presents the projected annual changes in Rs, clt, TAS, and wspd under both the RCP2.6 and RCP8.5 emission scenarios for the near future (2021-2040). The projections 
indicate an increase in solar irradiance and wind speed over western, central, and northern Africa under both RCPs. The projected increase of solar irradiance and wind speed ranges from $1 \%$ to more than $6 \%$, respectively, and is more widespread under the RCP8.5 than the RCP2.6 scenario. The southernmost parts of South Africa exhibit an increase in solar irradiance only under RCP8.5, with a corresponding significant decrease in total cloud cover. In general, a decrease in solar irradiance is found over most of East Africa under both emission scenarios with a slight increase in total cloud cover. TAS is projected to undergo a statistically significant increase of $\sim 0.8^{\circ} \mathrm{C}$ under RCP2.6 and $\sim 1.0^{\circ} \mathrm{C}$ under RCP8.5 over most of the continent.

Similar to the near future, the mid-century time slice (2041-2060) indicates a general increase of Rs, wspd, and TAS, and a decrease in clt over the continent (Fig. 7). In both emission scenarios, the changes in Rs, clt, TAS, and wspd are greater for the middle future than the near future. The projections are characterised in the mid-century by an increase in Rs over Southern Africa under RCP2.6 and a slight decrease under RCP8.5. In both scenarios, Western and Northern Africa are projected to experience an increase in Rs of about $1 \%$. This result contradicts the projected decrease of Rs over West Africa found by Sawadogo et al. (2019b), Bichet et al. (2019) and Bazyomo et al. (2016), but agrees on a slight increase of Rs in some parts of Southern Africa found by Bichet et al. (2019). The differences could be due to the number of models and specific GCMs used, the spatial resolution, or the internal configuration of the RegCM4 compared to other RCMs used in previous studies (Nikulin et al. 2018; Jerez et al. 2018; Giorgi 2010). The increase of Rs here is consistent with the projected decrease of clt (up to 8\%). Concerning TAS, when averaged over the entire continent the RCP8.5 indicates a warming by midcentury of $\sim 2.0{ }^{\circ} \mathrm{C}$, and the RCP2.6 a warming of $\sim 1.0{ }^{\circ} \mathrm{C}$.

\subsubsection{Projected changes in energy potential}

Figures 8 and 9 present the projected annual change in energy potential under the RCP2.6 and RCP8.5 emission scenarios in the near future and mid-century time slice, respectively. The main conclusion from these figures is that the sign of the changes is consistent across scenarios, but more intense and significant in the mid-century slice under the RCP8.5 scenario. The exception occurs for CSPOUT, which is more intense in mid-century under RCP2.6. In general, the Rmean shows a general increase of CSPOUT (up to $2 \%$ ) over Africa, which is consistent with Wild et al. (2017). This can be explained by the increase of Rd (which is used in Eq. 3 to compute the direct irradiance) over the WAF, $\mathrm{NAF}$, and SAF regions for the RCP2.6 in the mid-century (Fig. 7a). This is in line with the study of Crook et al. (2011) showing that the concentrated solar power technology is more sensitive to direct insolation.

The projected changes in PVP exhibit, however, a different signal over the continent. In both emission scenarios, the Rmean shows an increase over parts of WAF, CAF, and the eastern portions of SAF and a decrease elsewhere in the near future. The RCP2.6 shows a consistent pattern in the mid-century slice, but with a slight increase over the Eastern CAF region. For the RCP8.5 scenario, in the midcentury future, the Rmean suggests a general decrease of PVP over the continent except for some parts of CAF. The highest decrease (more than 1\%) is located over the Horn of Africa, western SAF, western Madagascar, NAF, and some parts of WAF. These results agree with previous studies that projected prevailing decreases in PVP over Africa in the future (Sawadogo et al. 2019b; Bichet et al. 2019; Bazyomo et al. 2016). The decrease in PVP over Africa could likely be attributed to the high increase in TAS under RCP8.5 in the mid-century future, since previous studies have shown that PVP technology is sensitive to the ambient temperature (Jerez et al. 2015; Patt et al. 2013).

The projected changes in WPD exhibit a consistent pattern for both future periods and emission scenarios, but with different magnitudes. Specifically, the WPD is projected to increase mainly over some parts of WAF and NAF $(\sim 30 \%)$, which agrees with results from Sawadogo et al. (2019a) over WAF under RCP8.5.

It is interesting to note that regions such as Southern Africa, where the model projects a future increase in WPD (Figs. 8 and 9), are characterized by future decreases in PVP, irrespective of the emission scenarios and the period analysed. These results highlight the need for combining both wind and solar energy as energy strategies in such regions. In terms of wind farms, Fig. 8 suggests central-west NAF and the Horn of Africa as the most favorable to consider for renewable energy investments since in the present and future climates they show high potential for wind energy generation.

Figure 10 provides a first order illustration of the robustness of the projection of renewable energy potential over the different African sub-regions using the interquartile spread as a measure. The spread is obtained by first averaging for each year of the reference period and future slices the region-mean values of the three simulations (HadGEM2-ES, MPI-ES-MR, and NorESM-1 M) and then taking a year-by-year difference of future minus reference values (i.e. year 1 of future minus year 1 of reference, year 2 of future minus year 2 of references and so on). This results in an ensemble of 20 change values, which allow us to construct quantile box plots. The robustness is then measured by the position of the inter-quantile range with respect to the 0 line, implying that if the interquartile range 
is fully above or below the line, there is an agreement, and thus more robustness, on the sign of the change.

With this definition, the level of robustness of the RegCM4 simulations differs depending on the region, emission scenario and future period considered. Under both the RCP2.6 and RCP8.5, we find a projected decrease in PVP in the near and mid-century future in all subregions, with this agreement being most robust (in the sense defined above) in the mid-century, RCP85 time slice. This implies a possible decrease in the potential electricity production based on solar photovoltaic technology. Conversely, CSPOUT is projected to increase for most sub-regions although with less robustness based on the interquartile range. Concerning the WPD projections, we find a consistent and robust signal of increase over all sub-regions and both periods and RCPs. NAF presents the highest increase in WPD, up to $18 \%$.

The uncertainties (in terms of magnitude) associated with the projections of PVP, CSPOUT, and WPD are due to the driving GCMs or/and the RCP scenario. Among the individual members, the projected changes are most pronounced in the experiment where RegCM4 is driven by HadGEM2-ES (see Appendix; Figs. 13, 14, 15, 16, 17, 18, 19 and 20). The largest uncertainties are found in the solar-related variables because these depend on cloudiness, which is one of the most difficult variables to describe in climate models, and on possible variations in aerosol loading, which are not included in the RegCM4 simulations and are anyways characterized by large uncertainties.

\section{Conclusions}

This study investigated the potential impacts of climate change on PVP, CSPOUT, and WPD under the RCP2.6 and RCP8.5 climate change scenarios in order to better understand the vulnerability of solar and wind energy potential to climate change over Africa. A high horizontal resolution ( $25 \mathrm{~km}$ grid spacing) ensemble of three RegCM4 twenty-first century projections completed as part of the CORDEX-CORE initiative was analyzed both for a present-day reference period (1995-2014) and two future time slices, a near term (2021-2040) and a midcentury one (2041-2060), with three driving GCMs. The findings of our study can be summarized as follows:

- The individual RegCM4 members and their ensemble mean (Rmean) simulate reasonably well the spatial pattern of solar irradiance, cloud cover, air temperature, and wind speed at $100 \mathrm{~m}$ AGL, but with some biases over different sub-regions, especially for cloud cover. The spatial correlations with observations exceed 0,98 for certain variables (see Figs. 2 and 3), and the RCM ensemble provides substantial added value compared to the driving GCMs especially for TAS and wspd;

- The different simulation members and their Rmean also reproduce the basic observed spatial distribution of PVP, CSPOUT, and WPD over the continent, but with some biases as well, most noticeably for PVP and CSPOUT;

- Projections under the RCP2.6 and RCP8.5 emission scenarios indicate an increase in solar irradiance (as a result of a decrease in total cloud cover) and wind speed for the near and middle future over most of Africa. Exceptions are some regions in the northeastern and southwestern parts of the continent;

- In general, the projected changes for the renewable energy potential in the near and mid-century future are consistent in both RCPs but more intense in the RCP8.5 scenario. We find a prevailing decrease in PVP, increase in WPD, and mixed results in CSPOUT;

- Regions with high wind intensity in the present climate, such as northwestern Africa and the Horn of Africa, will continue to present this feature in the mid-century, in fact with increased potential. Thus, based on our simulations, such regions would be appropriate for wind farm investments.

Given the different responses of different energy sources, complementary energy strategies should be used in different regions. The results of this study are consistent with, and thus reinforce, a number of previous findings over the continent (Sawadogo et al. 2019a, b; Soares et al. 2019b, and Bichet et al. 2019), although the magnitude of changes found in this study appear smaller than in previous ones, and some differences are found over specific regions.

Although our results provide useful additional information on the issue of the potential impact of climate change on PVP, CSPOUT, and WPD over Africa, they can be improved in several ways. A larger simulation ensemble with more driving GCMs would provide more robust information (Rozante et al. 2014), as would the analysis of different RCMs using the CORDEX-CORE simulation protocol. The availability of different RCMs in the CORDEX-CORE framework would also be important to better assess the differences between RCMs and GCMs in the projected changes. Additionally, high temporal resolution (hourly) model outputs are necessary for a more accurate renewable energy assessment and will help to consider diurnal variations of different parameters, which are especially important for solar-related variables. The current spatial resolution of the CORDEX-CORE protocol is higher than that of the CORDEX-phase I $(50 \mathrm{~km})$. Nonetheless, it is not sufficient to capture mesoscale circulations (sea breeze, mountain winds), which require $2-10 \mathrm{~km}$ resolution (Abbs and Physick 1992). The increasing use of RCMs at convection-permitting resolutions (e.g. Prein 
et al. 2013; Coppola et al. 2018), would offer the opportunity to better represent mesoscale systems along with the diurnal cycle of convective clouds, which would enable a more accurate estimate of the solar resource. Moreover, the current CORDEX simulations do not include the radiative effects of natural and anthropogenic aerosols, which can be important for an assessment of solar energy. We are in the process of assessing all these model uncertainties in future work to produce further improved information for renewable energy planning and to help stakeholders in building strategies for climate change adaptation.

Acknowledgements Open Access funding provided by Projekt DEAL. The authors would like to thank European Centre for Medium-range Weather Forecast (ECMWF) for the ERAINT reanalysis, National Council for Scientific and Technology Development (CNPq-Brazil), Centre for Atmospheric Research (CAR-NASRDA), and the Abdus Salam International Centre for Theoretical Physics (ICTP) for their financial assistance. Ismaila Diallo is supported by the US National Science Foundation grant AGS-1419526. The authors also thank the three anonymous reviewers and the editor for their constructive comments/suggestions, which helped to improve the quality of the manuscript.

Open Access This article is licensed under a Creative Commons Attribution 4.0 International License, which permits use, sharing, adaptation, distribution and reproduction in any medium or format, as long as you give appropriate credit to the original author(s) and the source, provide a link to the Creative Commons licence, and indicate if changes were made. The images or other third party material in this article are included in the article's Creative Commons licence, unless indicated otherwise in a credit line to the material. If material is not included in the article's Creative Commons licence and your intended use is not permitted by statutory regulation or exceeds the permitted use, you will need to obtain permission directly from the copyright holder. To view a copy of this licence, visit http://creativecommons.org/licenses/by/4.0/.

\section{Appendix}

See Figs. 11, 12, 13, 14, 15, 16, 17, 18, 19 and 20.
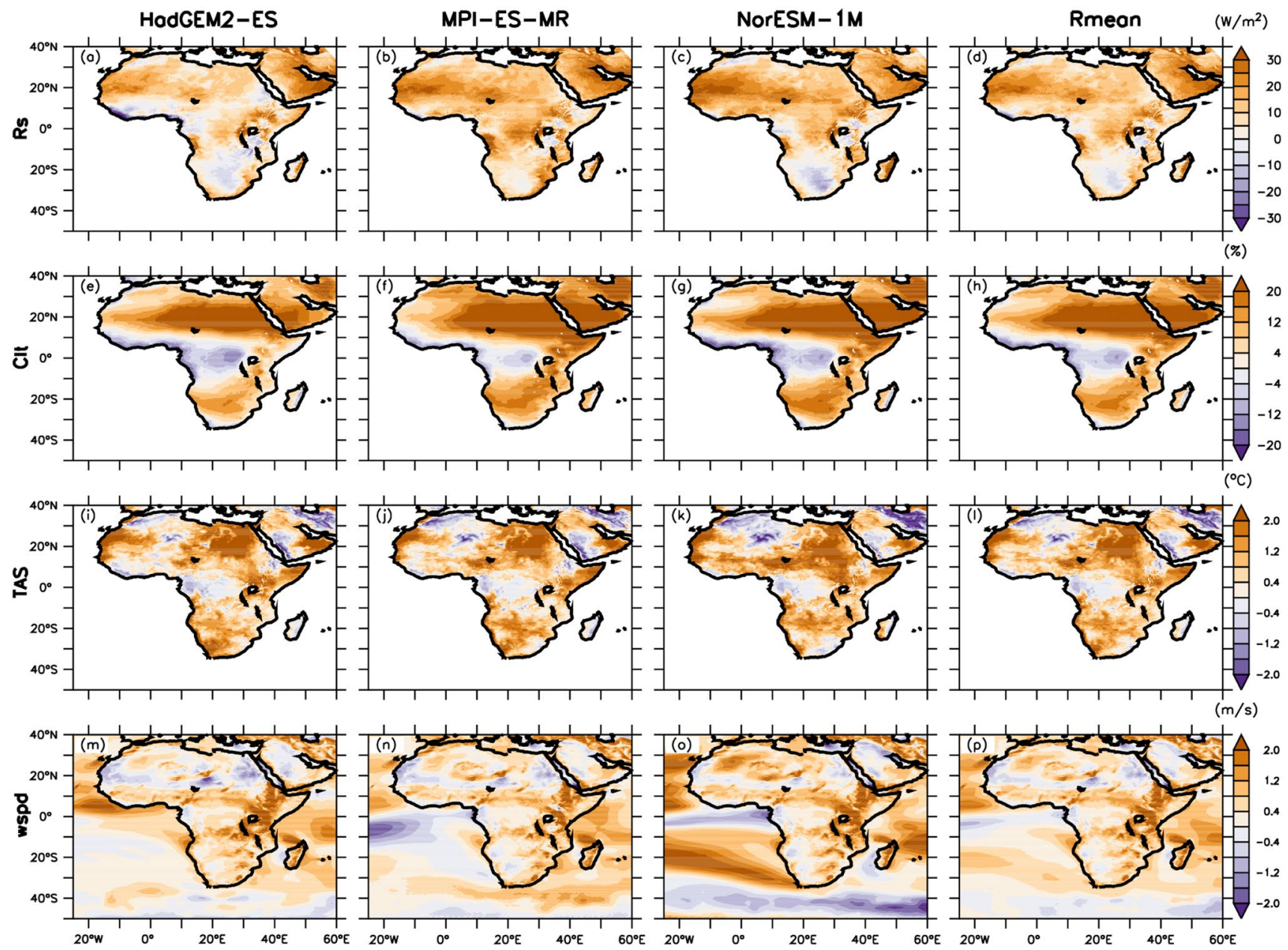

Fig. 11 Bias (simulations minus observations) of the annual mean of solar irradiance (Rs), total cloud cover (clt), air temperature (TAS), and wind speed (wspd) at $100 \mathrm{~m}$ AGL in the present climate (1995-

2014) of RegCM4 driven by three ESMs (HadGEM2-ES, MPI-ESMR, and NorESM-1 M) and their ensemble mean (Rmean) 

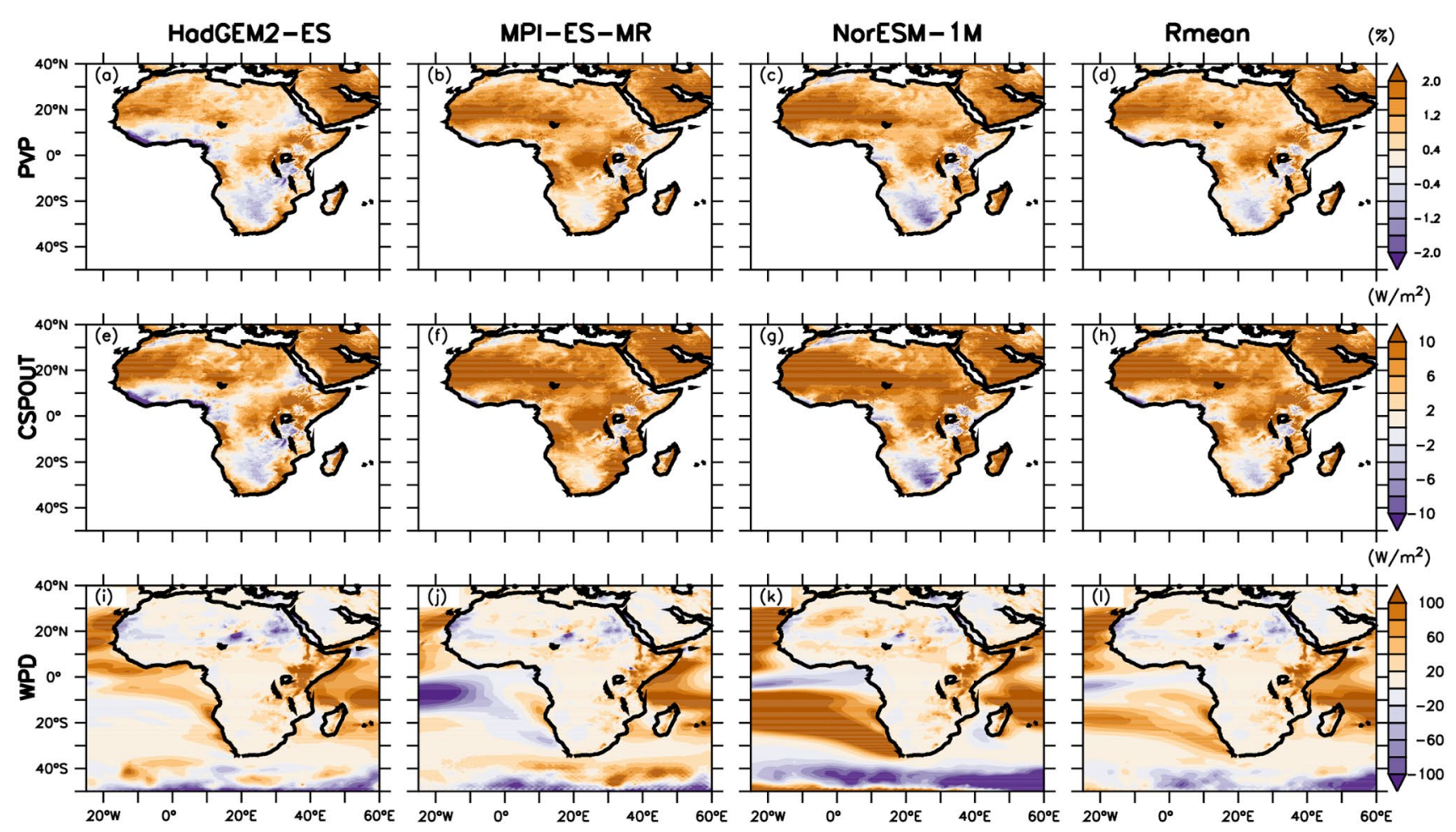

Fig. 12 Bias (simulations minus observations) of the annual mean of PV power potential (PVP), concentrated solar power out (CSPOUT), and wind power density (WPD) at $100 \mathrm{~m}$ above the ground level in

the present climate (1995-2014) of the RegCM4 driven by three ESMs (HadGEM2-ES, MPI-ES-MR, and NorESM-1 M) and their ensemble mean (Rmean) 

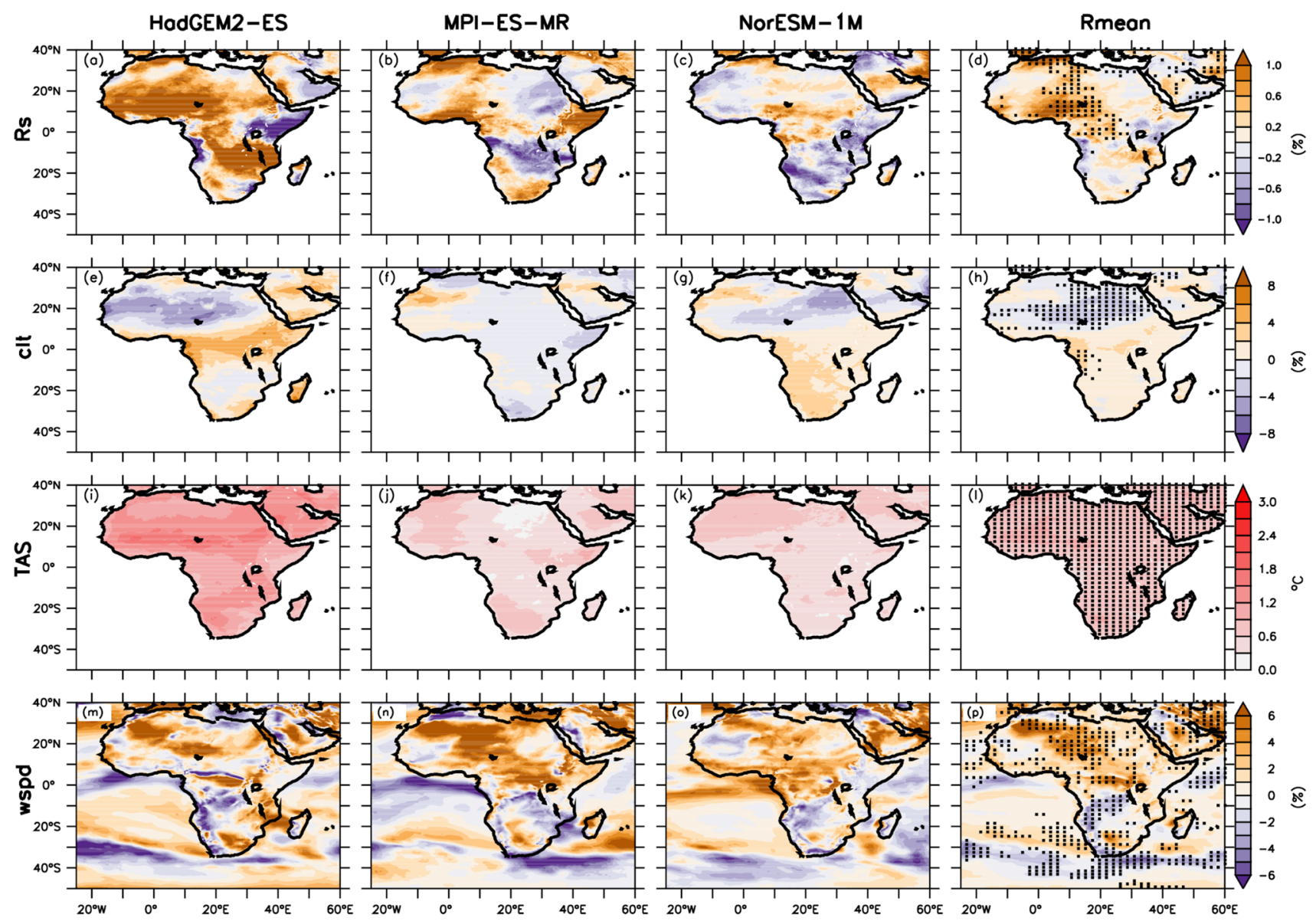

Fig. 13 Projected changes in the annual mean of solar irradiance (Rs), temperature (TAS), total cloud cover (clt), and wind speed at $100 \mathrm{~m}$ AGL over Africa in the near future (2021-2040) under RCP2.6 scenario with individual RegCM4 simulation driven by

three ESMs (HadGEM-2ES, MPI-ES-MR, and NorESM-1 M) and the ensemble mean (Rmean). The dot lines in the Rmean indicate the agreement where all the simulations exhibit the same signal change 

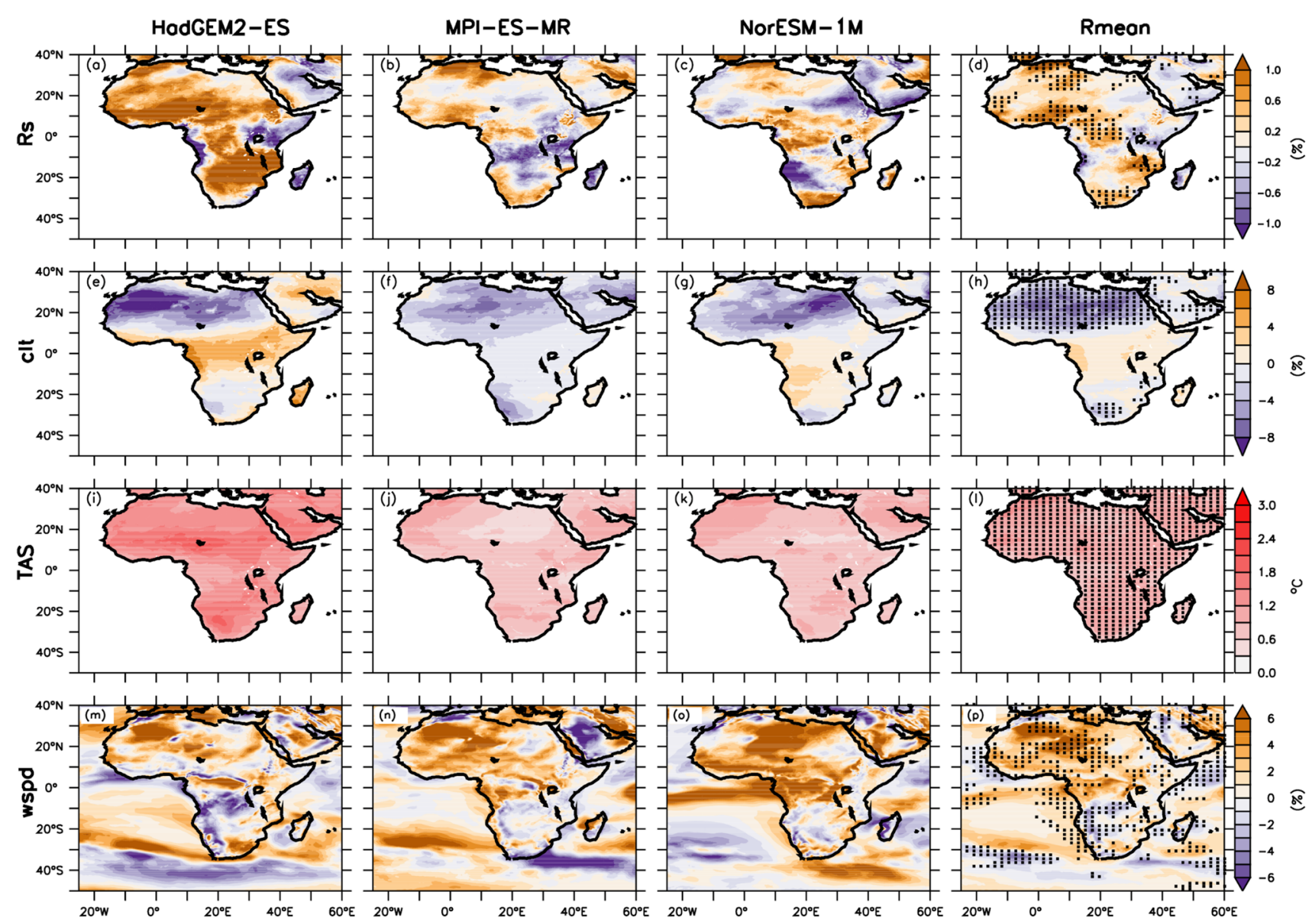

Fig. 14 Same as Fig. 13, but for the RCP8.5 scenario 

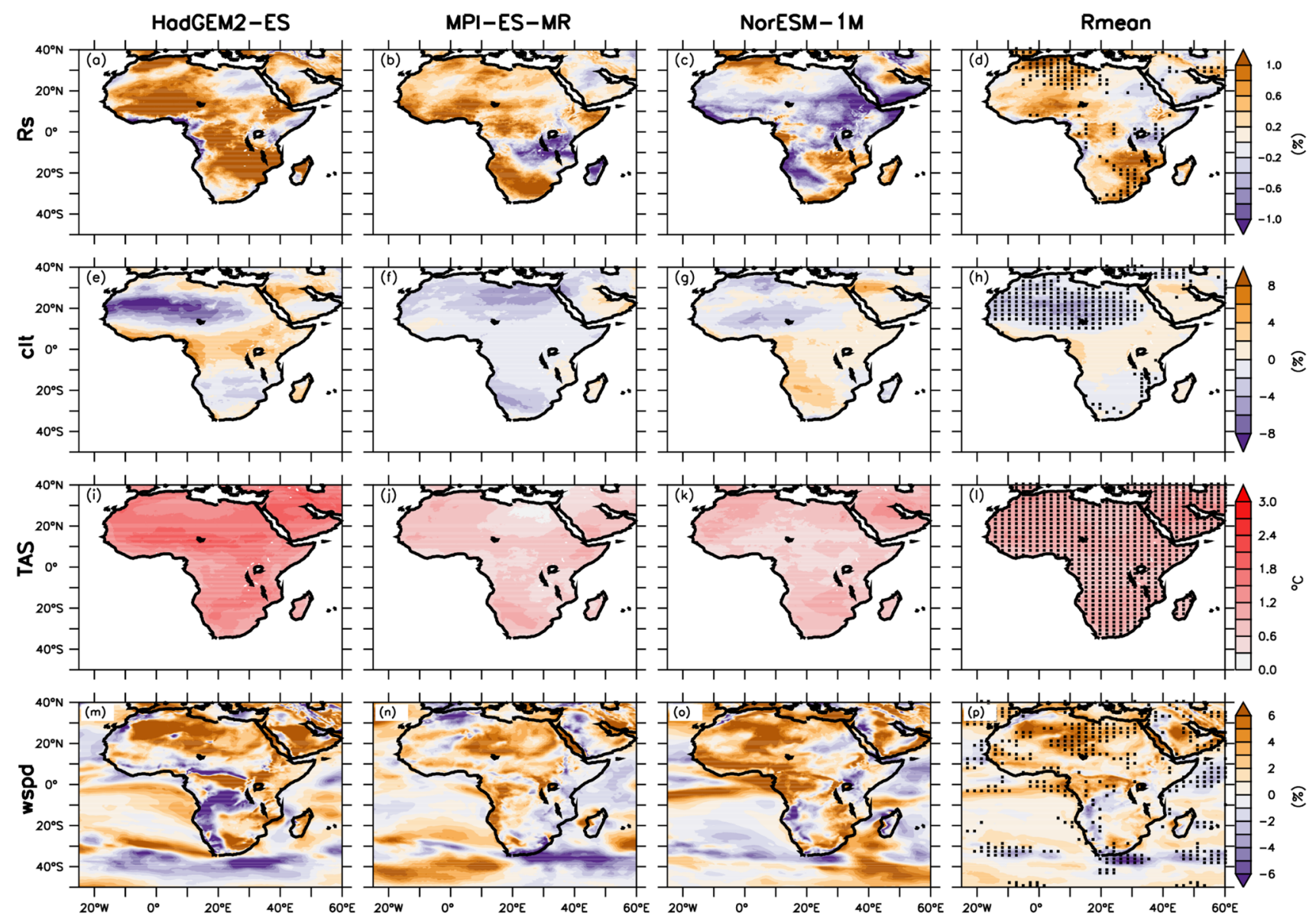

Fig. 15 Projected changes in the annual mean of solar irradiance (Rs), temperature (TAS), total cloud cover (clt), and wind speed at $100 \mathrm{~m}$ AGL over Africa in the middle future (2021-2040) under RCP2.6 scenario with individual RegCM4 simulation driven by

three ESMs (HadGEM-2ES, MPI-ES-MR, and NorESM-1 M) and the ensemble mean (Rmean). The dot lines in the Rmean indicate the agreement where all the simulations exhibit the same signal change 

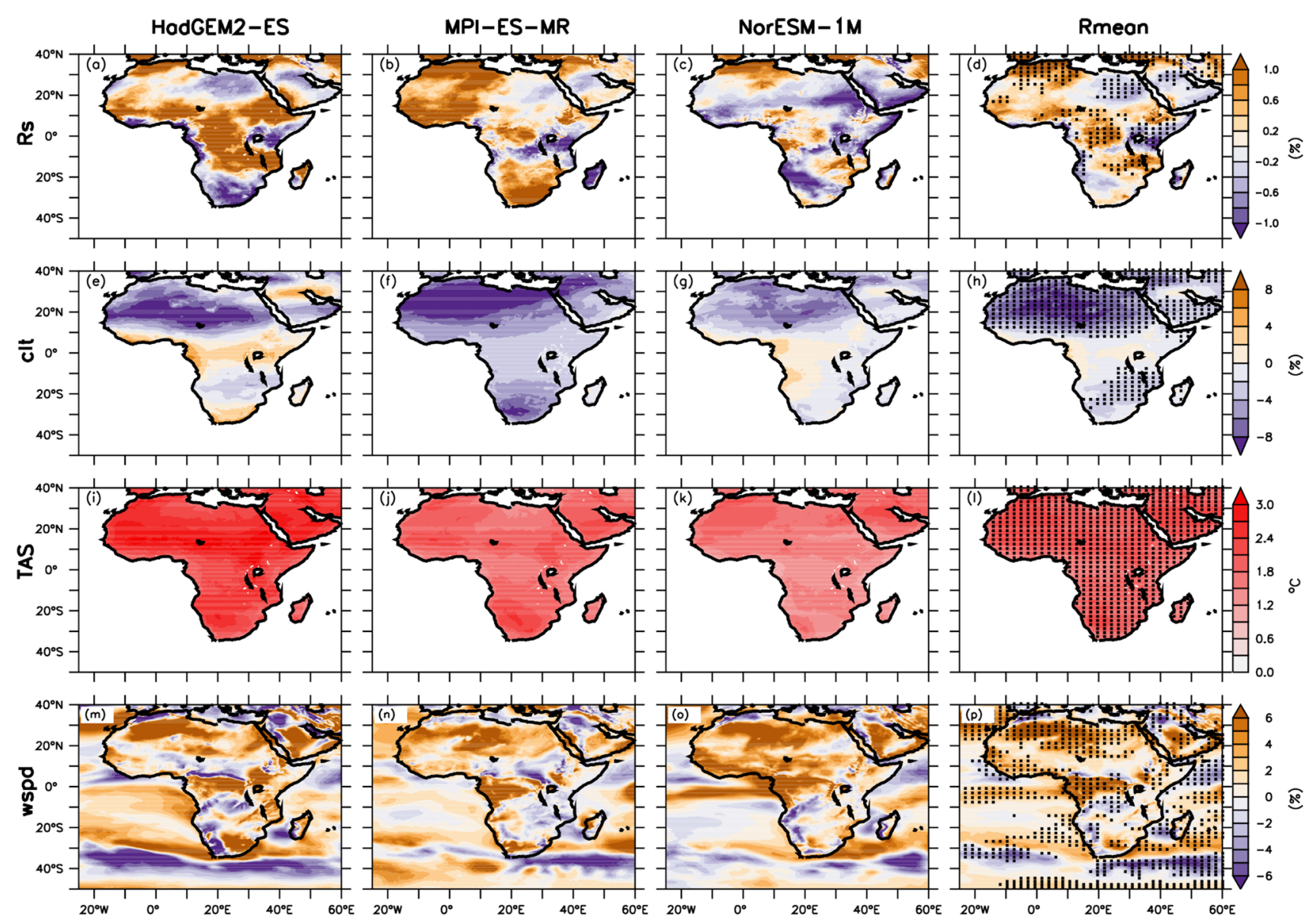

Fig. 16 Same as Fig. 15, but for the RCP8.5 scenario 

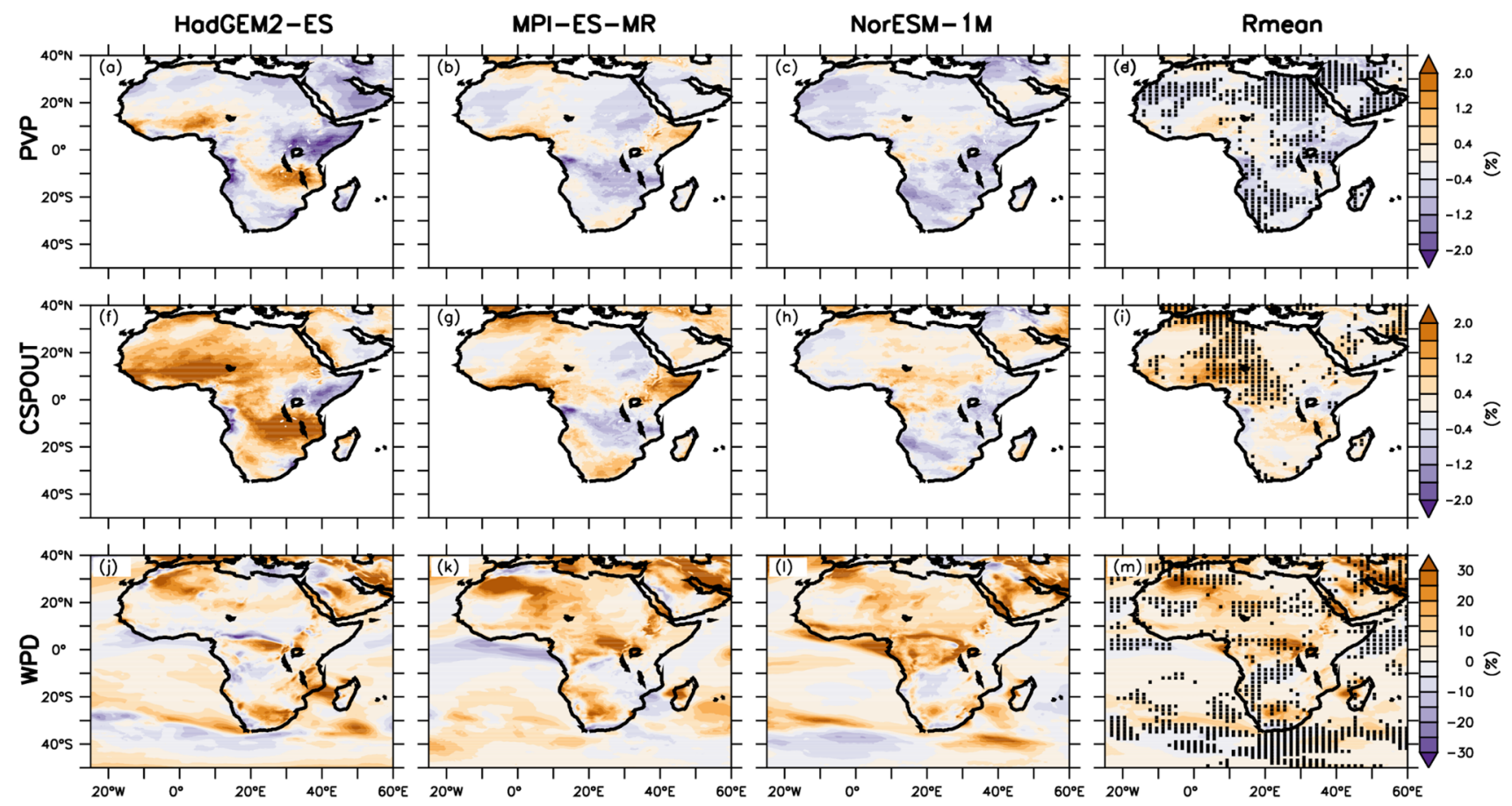

Fig. 17 Projected changes of individual RegCM4 simulation driven by three ESMs (HadGEM-2ES, MPI-ES-MR, and NorESM-1 M) and the ensemble mean (Rmean) in the annual mean of PV power potential (PVP), concentrated solar power out (CSPOUT), and wind power

density (WPD) at $100 \mathrm{~m}$ above the ground level over Africa in the near future (2021-2040) under RCP 2.6 scenario. The dot lines in the Rmean indicate the agreement where all the simulations exhibit the same signal change
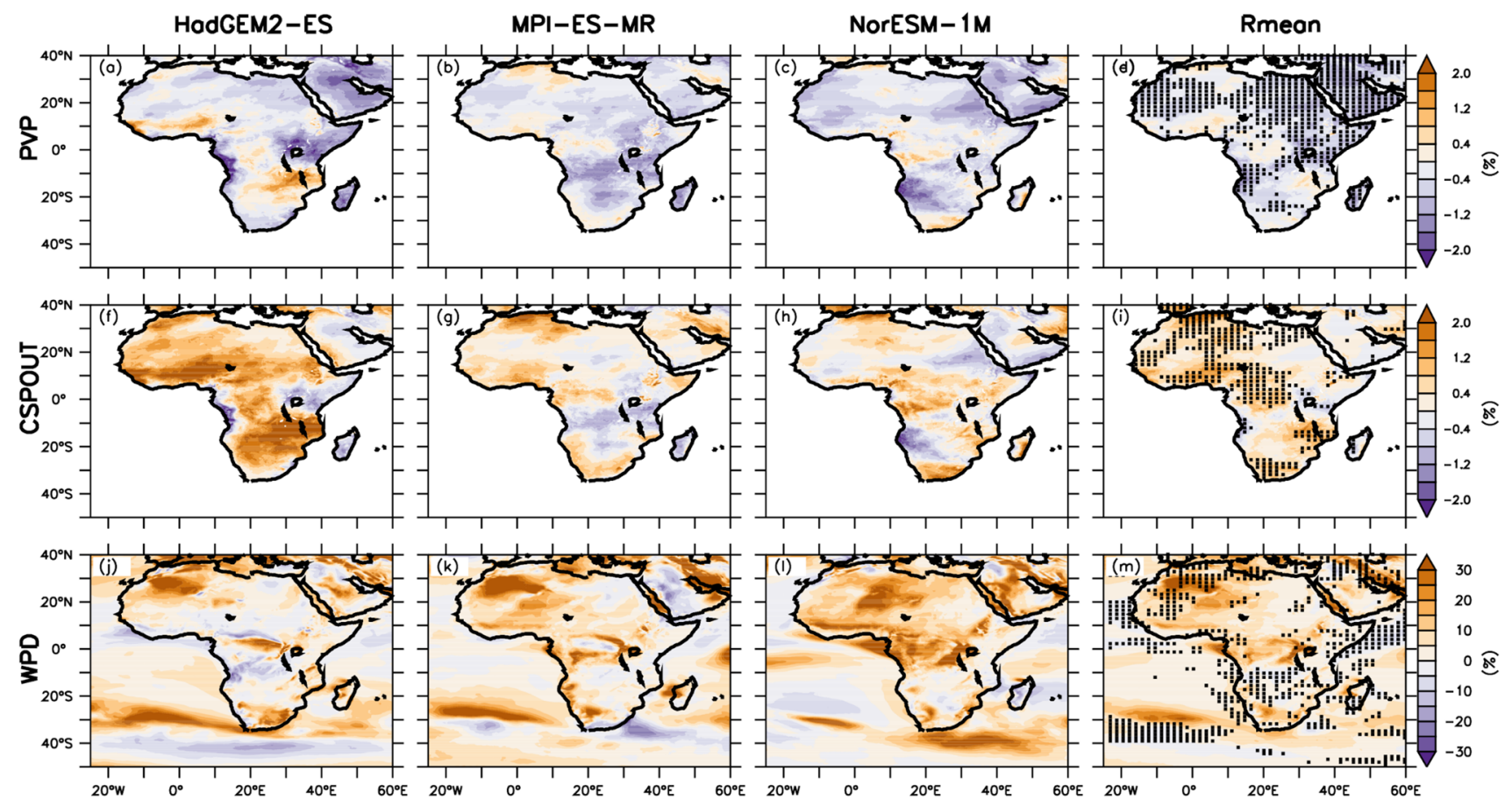

Fig. 18 Same as Fig. 17, but for the RCP8.5 scenario 

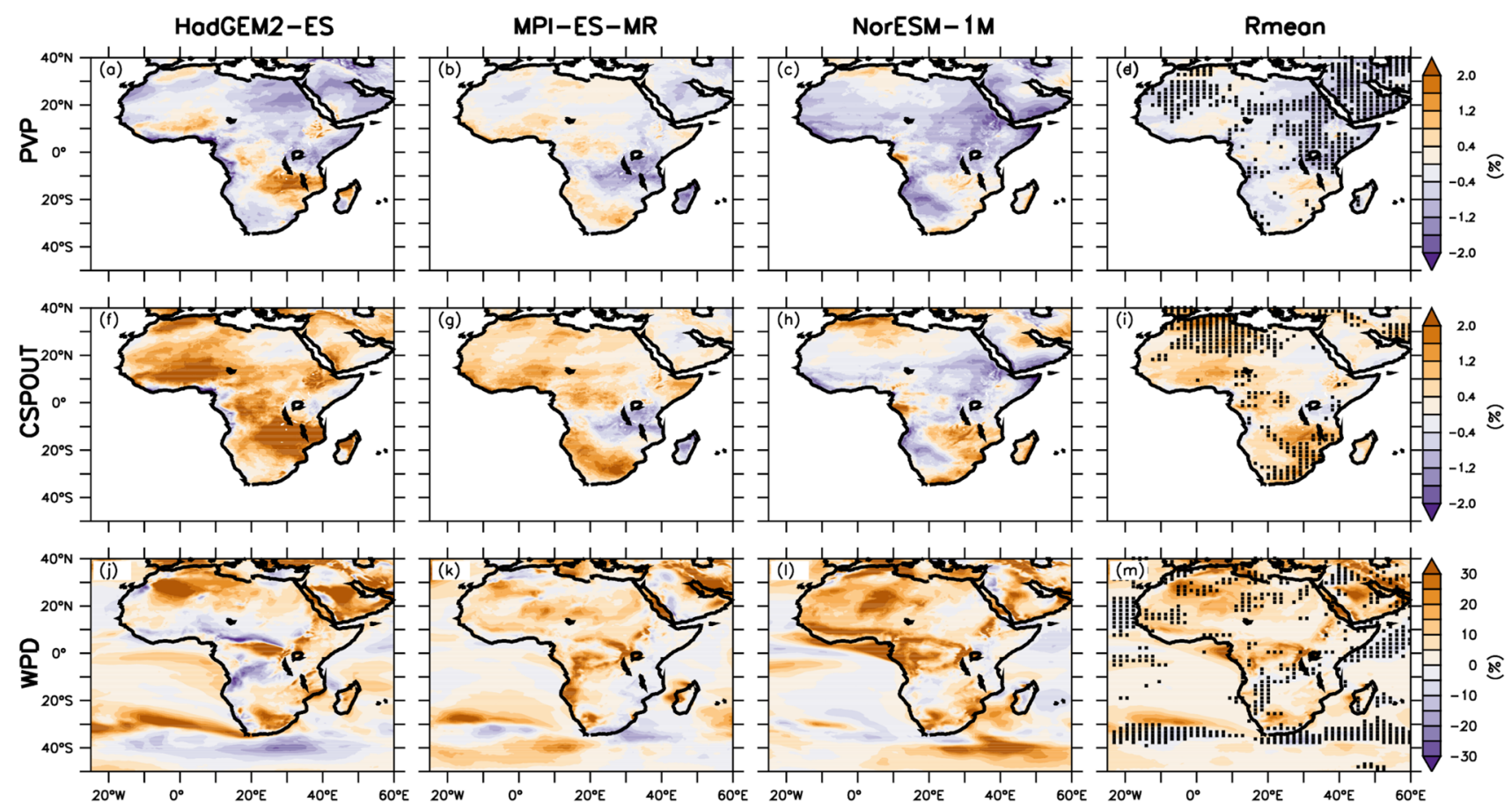

Fig. 19 Projected changes of individual RegCM4 simulation driven by three ESMs (HadGEM-2ES, MPI-ES-MR, and NorESM-1 M) and their ensemble mean (Rmean) in the annual mean of $\mathrm{PV}$ power potential (PVP), concentrated solar power out (CSPOUT), and wind power

density (WPD) at $100 \mathrm{~m}$ above the ground level over Africa in the middle future (2041-2060) under RCP2.6 scenario. The dot lines in the Rmean indicate the agreement where all the simulations exhibit the same signal change
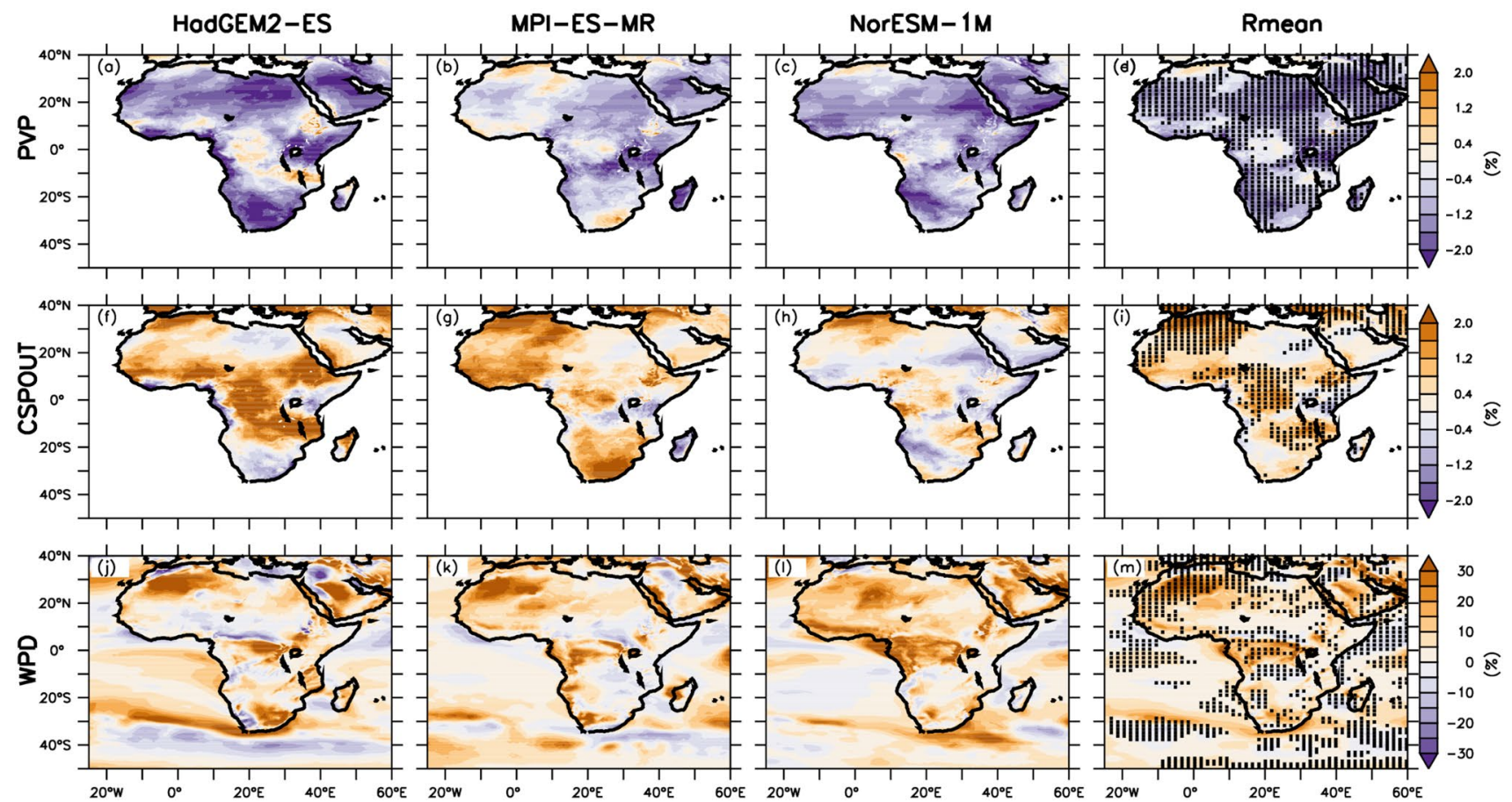

Fig. 20 Same as Fig. 19, but for the RCP8.5 scenario 


\section{References}

Abbs D, Physick WL (1992) Sea-breeze observations and modeling. Austr Meteor Mag 41:7-19

Albergel C, Munier S, Bocher A, Bonan B, Zheng Y, Draper C, Calvet JC (2018) LDAS-Monde sequential assimilation of satellite derived observations applied to the contiguous US: An ERA-5 driven reanalysis of the land surface variables. Remote Sens 10(10): 1627

Alstone P, Gershenson D, Kammen DM (2015) Decentralized energy systems for clean electricity access. Nature Climate Change. https ://doi.org/10.1038/nclimate2512

Avila NI, Kammen DM (2018) The role of renewable energy in bridging the electricity gap in Africa. Curr Sustain Renewable Energy Rep. https://doi.org/10.1007/s40518-018-0117-5

Bazyomo SDYB, Agnidé Lawin E, Coulibaly O, Ouedraogo A (2016) Forecasted changes in west africa photovoltaic energy output by 2045. Climate 4(4):53

Bentsen M, Bethke I, Debernard JB, Iversen T, Kirkevåg A, Seland $\varnothing$, Kristjánsson JE (2012) The Norwegian Earth System Model, NorESM1-M - Part 1: Description and basic evaluation. Geoscientific Model Development Discussions. https://doi.org/10.5194/ gmdd-5-2843-2012

Bertheau P, Oyewo AS, Cader C, Breyer C, Blechinger P (2017) Visualizing national electrification scenarios for sub-saharan African countries. Energies. https://doi.org/10.3390/en10111899

Bichet A, Hingray B, Evin G, Diedhiou AD, Kebe CMF, Anquetin S (2019) Potential impact of climate change on solar resource in Africa for photovoltaic energy: analyses from CORDEXAFRICA climate experiments. Environ Res Lett. https://doi. org/10.1088/1748-9326/ab500a

Boilley A, Wald L (2015) Comparison between meteorological reanalyses from ERA-Interim and MERRA and measurements of daily solar irradiation at surface. Renewable Energy 75:135-143

Braff WA, Mueller JM, Trancik JE (2016) Value of storage technologies for wind and solar energy. Nature Climate Change. https:// doi.org/10.1038/nclimate3045

Burnett D, Barbour E, Harrison GP (2014) The UK solar energy resource and the impact of climate change. Renewable Energy 71:333-343. https://doi.org/10.1016/J.RENENE.2014.05.034

Carvalho D, Rocha A, Gómez-Gesteira M, Silva Santos C (2017) Potential impacts of climate change on European wind energy resources under the CMIP5 future climate projections. Renewable Energy. https://doi.org/10.1016/j.renene.2016.08.036

Collins WJ, Bellouin N, Doutriaux-Boucher M, Gedney N, Hinton T, Jones CD, Liddicoat S, Martin G, O'Connor F, Rae J (2008) Evaluation of the HadGEM2 model. Met Office Exeter, UK

Coppola E, Sobolowski S, Pichelli E et al (2018) A first-of-its-kind multi-model convection permitting ensemble for investigating convective phenomena over Europe and the Mediterranean. Clim Dyn. https://doi.org/10.1007/s00382-018-4521-8

Crook JA, Jones LA, Forster PM, Crook R (2011) Climate change impacts on future photovoltaic and concentrated solar power energy output. Energy Environ Sci 4(9):3101. https://doi. org/10.1039/c1ee01495a

Davy R, Gnatiuk N, Pettersson L, Bobylev L (2018) Climate change impacts on wind energy potential in the European domain with a focus on the Black Sea. Renew Sustain Energy Rev. https://doi. org/10.1016/j.rser.2017.05.253

de Souza, E. P., Dias, P. L. da S., Plana-Fattori, A., \& Chagas, J. C. S. (1997). Absorption of solar radiation by water vapor in the atmosphere. Part II: Sensitivity tests with a general circulation model. Revista Brasileira de Geofísica, 15(3), 291-306.
Deardorff JW (1978) Efficient prediction of ground surface temperature and moisture, with inclusion of a layer of vegetation. J Geophys Res. https://doi.org/10.1029/jc083ic04p01889

dos Santos Custódio, R. (2009). Energia eólica para produção de energia elétrica. Eletrobrás.

Dubey S, Sarvaiya JN, Seshadri B (2013) Temperature Dependent Photovoltaic (PV) Efficiency and Its Effect on PV Production in the World - A Review. Energy Procedia 33:311-321. https://doi. org/10.1016/J.EGYPRO.2013.05.072

Dullaart JC, Muis S, Bloemendaal N, Aerts JC (2020) Advancing global storm surge modelling using the new ERA5 climate reanalysis. Clim Dyn 54(1-2):1007-1021

Edwards, J. M., \& Slingo, A. (1996). Studies with a flexible new radiation code. I: Choosing a configuration for a large-scale model. Quarterly Journal of the Royal Meteorological Society, 122(531), 689-719.

Elguindi N, Giorgi F, Turuncoglu UU (2014) Assessment of CMIP5 global model simulations over the sub-set of CORDEX domains used in the Phase I CREMA Experiment. Climatic Change 125(1):7-21. https://doi.org/10.1007/S10584-013-0935-9

Fant C, Schlosser CA, Strzepek K (2016) The impact of climate change on wind and solar resources in southern Africa. Appl Energy 161:556-564

Giorgetta MA, Jungclaus J, Reick CH, Legutke S, Bader J, Böttinger M, Stevens B (2013) Climate and carbon cycle changes from 1850 to 2100 in MPI-ESM simulations for the Coupled Model Intercomparison Project phase 5. J Adv Model Earth Syst. https://doi. org/10.1002/jame.20038

Giorgi, F., Jones, C., \& Asrar, G. R. (2009). Addressing climate information needs at the regional level: the CORDEX framework. World Meteorological Organization (WMO) Bulletin, 58(3), 175.

Giorgi F (2010) Uncertainties in climate change projections, from the global to the regional scale. EPJ Web Conferences 9:115-129. https://doi.org/10.1051/epjconf/201009009

Giorgi F, Coppola E, Solmon F, Mariotti L, Sylla MB, Bi X, Brankovic C (2012) RegCM4: Model description and preliminary tests over multiple CORDEX domains. Climate Res. https://doi. org/10.3354/cr01018

Gualtieri G, Secci S (2012) Methods to extrapolate wind resource to the turbine hub height based on power law: A 1-h wind speed vs. Weibull distribution extrapolation comparison. Renew Energy. https://doi.org/10.1016/j.renene.2011.12.022

Gutowski WJ, Giorgi F, Timbal B, Frigon A, Jacob D et al. (2016) WCRP Coordinated Regional Downscaling EXperiment (CORDEX): a diagnostic MIP for CMIP6. European Geosciences Union Geoscientific Model Development Discussions 9 11; 11-2016; 4087-4095

Hancock KJ (2015) The expanding horizon of renewable energy in subSaharan Africa: Leading research in the social sciences. Energy Res Social Sci. https://doi.org/10.1016/j.erss.2014.12.021

Hersbach H, Bell W, Berrisford P, et al (2019) Global reanalysis: goodbye ERA-Interim, hello ERA5. ECMWF Newsletter 159:17-24. https://doi.org/10.21957/vf291hehd7

Holtslag AAM, Boville BA (1993) Local versus nonlocal boundary-layer diffusion in a global climate model. J Clim 6(10):1825-1842

Holtslag AAM, De Bruijn EIF, Pan HL (1990) A high resolution air mass transformation model for short-range weather forecasting. Mon Weather Rev. https://doi.org/10.1175/15200493(1990)118<1561:AHRAMT>2.0.CO;2

Huber I, Bugliaro L, Ponater M, Garny H, Emde C, Mayer B (2016) Do climate models project changes in solar resources? Sol Energy 129:65-84. https://doi.org/10.1016/J.SOLENER.2015.12.016

IEA (2018) Global energy demand grew by $2.1 \%$ in 2017, and carbon emissions rose for the first time since 2014. Retrieved December 
27, 2019, from https://www.iea.org/news/global-energy-deman d-grew-by-21-in-2017-and-carbon-emissions-rose-for-the-first -time-since-2014

IEA (2019) "Renewables 2019", IEA, Paris. Retrieved December 27, 2019, from https://www.iea.org/reports/renewables-2019

Jerez S, López-Romero JM, Turco M, Jiménez-Guerrero P, Vautard R, Montávez JP (2018) Impact of evolving greenhouse gas forcing on the warming signal in regional climate model experiments. Nature Commun 9(1):1304

Jerez S, Tobin I, Vautard R, Montávez JP, López-Romero JM, Thais F et al (2015) The impact of climate change on photovoltaic power generation in Europe. Nature Commun 6:10014

Kåberger T (2018) Progress of renewable electricity replacing fossil fuels. Global Energy Interconn 1(1): 48-52. https://doi.org/10.14171 /J.2096-5117.GEI.2018.01.006

Kain JS, Fritsch JM (1990) A one-dimensional entraining/detraining plume model and its application in convective parameterization. $\mathrm{J}$ Atmospheric Sci 47(23):2784-2802

Kiehl T, Hack J, Bonan B, Boville A, Briegleb P Williamson L, Rasch J (1996) Description of the NCAR community climate model (CCM3)

Lasnier F, Ang TG (1990) Photovoltaic Engineering Handbook. Princeton, Adam Higler

Mariotti L, Diallo I, Coppola E, Giorgi F (2014) Seasonal and intraseasonal changes of African monsoon climates in 21 st century CORDEX projections. Clim Change 125:53-65. https://doi.org/10.1007/ s10584-014-1097-0

Matthews H, Gillett N, Stott P et al (2009) The proportionality of global warming to cumulative carbon emissions. Nature 459:829-832. https://doi.org/10.1038/nature08047

Matthews HD, Caldeira K (2008) Stabilizing climate requires near-zero emissions. Geophys Res Lett. https://doi.org/10.1029/2007GL0323 88

Mavromatakis F, Makrides G, Georghiou G, Pothrakis A, Franghiadakis Y, Drakakis E, Koudoumas E (2010) Modeling the photovoltaic potential of a site. Renewable Energy 35(7):1387-1390

Moss RH, Edmonds JA, Hibbard KA, Manning MR, Rose SK, Van Vuuren DP, Meehl GA (2010) The next generation of scenarios for climate change research and assessment. Nature 463(7282):747-756

Nasrin R, Hasanuzzaman M, Rahim NA (2018) Effect of high irradiation and cooling on power, energy and performance of a PVT system. Renewable Energy. https://doi.org/10.1016/j.renene.2017.10.004

Nikulin G, Lennard C, Dosio A, Kjellström E, Chen Y, Hänsler A et al (2018) The effects of 1.5 and 2 degrees of global warming on Africa in the CORDEX ensemble. Environm Res Lett 13(6):65003

Obama B (2017) The irreversible momentum of clean energy. Science. https://doi.org/10.1126/science.aam6284

Oleson KW, Niu GY, Yang ZL, Lawrence DM, Thornton PE, Lawrence PJ, Stöckli R, Dickinson RE, Bonan GB, Levis S(2008) Improvements to the Community Land Model and their impact on the hydrological cycle. J Geophysi Res: Biogeosci113(G1)

Owusu PA, Asumadu-Sarkodie S (2016) A review of renewable energy sources, sustainability issues and climate change mitigation. Cogent Eng. https://doi.org/10.1080/23311916.2016.1167990

Pal JS, Small EE, Eltahir EAB (2000) Simulation of regional-scale water and energy budgets: Representation of subgrid cloud and precipitation processes within RegCM. J Geophys Res Atmospheres. https ://doi.org/10.1029/2000JD900415

Patt A, Pfenninger S, Lilliestam J (2013) Vulnerability of solar energy infrastructure and output to climate change. Climatic Change 121(1):93-102

Pfeifroth U, Sanchez-Lorenzo A, Manara V, Trentmann J, Hollmann R (2018) Trends and variability of surface solar radiation in europe based on surface-and satellite-based data records. J Geophys Res Atmospheres 123(3):1735-1754
Prein A, Gobiet A, Suklitsch M, Truhetz H, Awan N, Keuler K, Georgievski G (2013) Added value of convection permitting seasonal simulations. Clim Dyn 41(9-10):2655-2677

Reboita MS, Amaro TR, de Souza MR (2017) Winds: intensity and power density simulated by RegCM4 over South America in present and future climate. Clim Dyn. https://doi.org/10.1007/s0038 2-017-3913-5

Rozante JR, Moreira DS, Godoy RCM, Fernandes AA (2014) Multimodel ensemble: Technique and validation. Geoscient Model Develop 7(5):2333-2343. https://doi.org/10.5194/gmd-7-2333-2014

Sawadogo W, Abiodun BJ, Okogbue EC (2019a) Projected changes in wind energy potential over West Africa under the global warming of $15{ }^{\circ} \mathrm{C}$ and above. Theoret Appl Climatol. https://doi.org/10.1007/ s00704-019-02826-8

Sawadogo W, Abiodun BJ, Okogbue EC (2019b) Impact of global warming on photovoltaic power generation over West Africa. Renewable Energy. https://doi.org/10.1016/j.renene.2019.11.032

Soares PM, Lima DC, Semedo A, Cabos W, Sein DV (2019a) Climate change impact on Northwestern African offshore wind energy resources. Environ Res Lett 14(12):124065

Soares PM, Brito MC, Careto JA (2019b) Persistence of the high solar potential in Africa in a changing climate. Environ Res Lett 14(12): 124036

Solomon S, Plattner G-K, Knutti R, Friedlingstein P (2009) Irreversible climate change due to carbon dioxide emissions. Proc Natl Acad Sci 106(6):1704-1709

Sylla MB, Coppola E, Mariotti L et al (2010) Multiyear simulation of the African climate using a regional climate model (RegCM3) with the high resolution ERA-interim reanalysis. Clim Dyn 35:231-247. https://doi.org/10.1007/s00382-009-0613-9

Tall M, Albergel C, Bonan B, Zheng Y, Guichard F, Dramé MS, Calvet JC (2019) Towards a long-term reanalysis of land surface variables over Western Africa: LDAS-Monde Applied over Burkina Faso from 2001 to 2018. Remote Sens 11(6):735

TamizhMani G, Ji L, Tang Y, Petacci L, Osterwald C (2003) Photovoltaic module thermal/wind performance: long-term monitoring and model development for energy rating. In NCPV and Solar Program Review Meeting Proceedings, 24-26 March 2003, Denver, Colorado (CD-ROM)

Tang C, Morel B, Wild M, Pohl B, Abiodun B, Lennard C, Bessafi M (2019) Numerical simulation of surface solar radiation over Southern Africa. Part 2: projections of regional and global climate models. Clim Dyn 53:2197-2227. https://doi.org/10.1007/s0038 2-018-4143-1

Tiedtke M (1989) A comprehensive mass flux scheme for cumulus parameterization in large-scale models. Mon Weather Rev 117(8):1779-1800

Tobin I, Greuell W, Jerez S, Ludwig F, Vautard R, Van Vliet MTH, Breón FM (2018) Vulnerabilities and resilience of European power generation to $1.5^{\circ} \mathrm{c}, 2^{\circ} \mathrm{c}$ and $3{ }^{\circ} \mathrm{C}$ warming. Environm Res Lett. https://doi. org/10.1088/1748-9326/aab211

Torma C, Giorgi F, Coppola E (2015) Added value of regional climate modeling over areas characterized by complex terrain-Precipitation over the Alps. J Geophys Res Atmos 120(9):3957-3972

Wallace JM, Hobbs PV (2006) Atmospheric Science: An Introductory Survey: Second Edition. Atmospheric Science: An Introductory Survey: Second Edition. https://doi.org/10.1016/C2009-0-00034-8

Wang C, Graham RM, Wang K, Gerland S, Granskog MA (2019) Comparison of ERA5 and ERA-Interim near-surface air temperature, snowfall and precipitation over Arctic sea ice: effects on sea ice thermodynamics and evolution. Cryosphere 13(6):1661-1679

Wilcox LJ, Highwood EJ, Dunstone NJ (2013) The influence of anthropogenic aerosol on multi-decadal variations of historical global climate. Environ Res Lett 8(2):024033 
Wild M, Folini D, Henschel F (2017) Impact of climate change on future concentrated solar power (CSP) production. In AIP Conference Proceedings 1810: 100007

Wild M, Folini D, Henschel F, Fischer N, Müller B (2015) Projections of long-term changes in solar radiation based on CMIP5 climate models and their influence on energy yields of photovoltaic systems. Sol Energy 116:12-24. https://doi.org/10.1016/J.SOLEN ER.2015.03.039

Wu F, Fu C (2011) Assessment of GEWEX/SRB version 3.0 monthly global radiation dataset over China. Meteorol Atmos Phys. https:// doi.org/10.1007/s00703-011-0136
Zeng X, Zhao M, Dickinson RE (1998) Intercomparison of bulk aerodynamic algorithms for the computation of sea surface fluxes using TOGA COARE and TAO data. J Clim. https://doi.org/10.1175/15200442(1998)011<2628:IOBAAF>2.0.CO;2

Publisher's Note Springer Nature remains neutral with regard to jurisdictional claims in published maps and institutional affiliations.

\section{Affiliations}

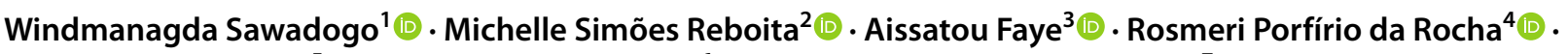

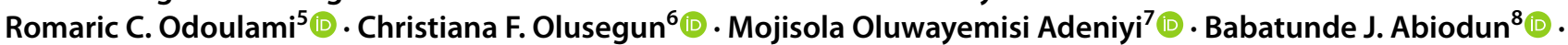 Mouhamadou Bamba Sylla ${ }^{9} \cdot$ Ismaila Diallo ${ }^{10} \cdot$ Erika Coppola $^{11} \cdot$ Filippo Giorgi $^{11}$}

Michelle Simões Reboita

reboita@unifei.edu.br

Aissatou Faye

aichafaye8@gmail.com

Rosmeri Porfírio da Rocha rosmerir.rocha@iag.usp.br

Romaric C. Odoulami

romaric.odoulami@uct.ac.za

Christiana F. Olusegun

chrystali2002@gmail.com

Mojisola Oluwayemisi Adeniyi

mojisolaadeniyi@yahoo.com

Babatunde J. Abiodun

babiodun@csag.uct.ac.za

Mouhamadou Bamba Sylla

syllabamba@yahoo.fr; sylla.bamba@aims.ac.rw

Ismaila Diallo

idiallo@ucla.edu

Erika Coppola

coppolae@ictp.it

Filippo Giorgi

giorgi@ictp.it

1 Institute of Geography, University of Augsburg, Augsburg,

Germany
2 Federal University of Itajubá, UNIFEI, Av. BPS, 1303, Itajubá, Minas Gerais, Brazil

3 Department of Environmental Sciences, University of Virginia, Charlottesville, VA 220904, USA

4 Departamento de Ciências Atmosféricas, Universidade de São Paulo (USP), São Paulo, Brazil

5 African Climate and Development Initiative, University of Cape Town, Cape Town, South Africa

6 Centre for Atmospheric Research, National Space Research and Development Agency (CAR-NASRDA), Anyigba, Nigeria

7 Department of Physics, University of Ibadan, Ibadan, Nigeria

8 Climate System Analysis Group, Department of Environmental and Geographical Science, University of Cape Town, Cape Town, South Africa

9 African Institute for Mathematical Sciences (AIMS), AIMS Rwanda Center, Kigali, Rwanda

10 Department of Geography, University of California-Los Angeles, Los Angeles, CA 90095, USA

11 Earth System Physics, ESP, The Abdus Salam International Centre for Theoretical Physics, Trieste, Italy 